\title{
FIRE AND VEGETATION EFFECTS ON PRODUCTIVITY AND NITROGEN CYCLING ACROSS A FOREST-GRASSLAND CONTINUUM
}

\author{
Peter B. Reich, ${ }^{1}$ David W. Peterson, ${ }^{1}$ David A. Wedin, ${ }^{2}$ and Keith Wrage ${ }^{1}$ \\ ${ }^{1}$ Department of Forest Resources, University of Minnesota, St. Paul, Minnesota 55108 USA \\ ${ }^{2}$ School of Natural Resource Sciences, University of Nebraska, Lincoln, Nebraska 68583 USA
}

\begin{abstract}
Mixed tree-grass vegetation is important globally at ecotones between grasslands and forests. To address uncertainties vis-à-vis productivity and nitrogen $(\mathrm{N})$ cycling in such systems we studied 20 mature oak savanna stands, ranging from $90 \%$ woody dominated to $80 \%$ herbaceous dominated, growing on comparable soils in a 32 -yr-old fire frequency experiment in Minnesota, USA. Fire frequencies ranged from almost annual burning to complete fire protection. Across all stands, aboveground net primary productivity (ANPP) ranged from 2 to $12 \mathrm{Mg} \cdot \mathrm{ha}^{-1} \cdot \mathrm{yr}^{-1}$, decreased with fire frequency $\left(r^{2}=0.59\right)$, increased with woody canopy dominance $\left(r^{2}=0.83\right)$, and increased with soil net $\mathrm{N}$ mineralization rates $\left(r^{2}=0.79\right)$, which varied from 25 to $150 \mathrm{~kg} \cdot \mathrm{ha}^{-1} \cdot \mathrm{yr}^{-1}$. ANPP was positively related to total biomass $\left(r^{2}=0.95\right)$, total canopy leaf $\mathrm{N}$ content $\left(r^{2}=0.88\right)$, leaf area index (LAI; $\left.r^{2}=0.87\right)$, annual litterfall $\mathrm{N}$ cycling $\left(r^{2}=0.70\right)$, foliage $\mathrm{N}$ concentration $\left(r^{2}=\right.$ $0.62)$, and fine root $\mathrm{N}$ concentration $\left(r^{2}=0.35\right)$, all of which also increased with increasing tree canopy cover. ANPP, soil $\mathrm{N}$ mineralization, and estimated root turnover rates increased with woody canopy cover even for stands with similar fire frequency. ANPP and N mineralization both decreased with fire frequency for stands having a comparable percentage of woody canopy cover. Fine root standing biomass increased with increasing grass dominance. However, fine root turnover rate estimated with a nitrogen budget technique decreased proportionally more with increasing grass dominance, and hence fine root productivity decreased along the same gradient.

Via several direct and indirect and mutually reinforcing (feedback) effects, the combination of low fire frequency and high tree dominance leads to high rates of $\mathrm{N}$ cycling, LAI, and productivity; while the opposite, high fire frequency and high grass dominance, leads to low rates of $\mathrm{N}$ cycling, LAI, and productivity. Carbon and $\mathrm{N}$ cycling were tightly coupled across the fire frequency and vegetation type gradients.
\end{abstract}

Key words: aboveground net primary productivity (ANPP); fire and productivity; food-grassland ecotones; leaf area index; mineralization; nitrogen cycling; oak; primary production; roots; savanna.

\section{INTRODUCTION}

The ecotone between forest and grassland biomes provides a number of ecological puzzles involving issues such as stability, the role of disturbance, and controls on composition, productivity and nutrient cycling (Scholes and Archer 1997). Although we know an increasing amount about the influence of trees on grassy vegetation (e.g., Jackson et al. 1990, Belsky 1994, Haworth and McPherson 1994, Scholes and Archer 1997) via effects on light, water, and nutrient cycling, we know less about the dynamics of these ecosystems as a whole. In particular, although much effort has been directed at understanding controls on productivity for forests (e.g., Nadelhoffer et al. 1985, Gower et al. 1992, Gholz et al. 1994, Reich et al. 1997) and grasslands (e.g., Risser et al. 1981, Knapp et al. 1993, 1998) this is not as true for savannas (Mitchell et al. 1999a). Hence, the objective of the current paper is to characterize the role of disturbance (fire) and vegetation type in controlling $\mathrm{N}$ cycling and productivity in sa-

Manuscript received 4 October 1999; revised 19 June 2000; accepted 19 June 2000. vanna ecosystems along a local forest-grassland continuum in Minnesota, USA.

Common garden studies developed on common soils and climate have demonstrated differences in productivity and nitrogen $(\mathrm{N})$ cycling for different species within a functional type such as grasses or trees (Wedin and Tilman 1990, Gower et al. 1993, Binkley 1995). However, it is not known how grassland- and woodland-dominated ecosystems differ in carbon (C) and $\mathrm{N}$ cycling relationships and rates when growing on similar substrates. Although aboveground net primary production (ANPP) was positively related to soil net $\mathrm{N}$ mineralization rates in central North American forests (Reich et al. 1997), this was not the case for central North American grasslands (Turner et al. 1997). The comparison of grasslands and forests is complicated by fire, which was a more frequent natural disturbance in grasslands than woodlands, and has both direct and indirect effects on $\mathrm{N}$ cycling and productivity (Ojima et al. 1994). Fire often has a short-term stimulatory effect on $\mathrm{N}$ availability to individual plants (i.e., supply minus demand) and resulting ecosystem physiology (Reich et al. 1990) but a negative long-term effect due 
to elevated N losses from the ecosystem (Raison 1979, Ojima et al. 1994).

Rates of $\mathrm{C}$ and $\mathrm{N}$ cycling may become uncoupled as human activities lead to ever increasing rates of $\mathrm{N}$ additions (Asner et al. 1997) or may be naturally uncoupled when other factors are influential (Turner et al. 1997, Mitchell et al. 1999a). The very nature of C:N interactions is unclear as well. Although models and experimental evidence suggest that differences in intrinsic traits of species can lead to plant-induced feedbacks that result in divergence of both productivity and $\mathrm{N}$ cycling among stands along soil fertility gradients (Pastor et al. 1984, Wedin and Tilman 1990, Aerts 1992, Gower and Son 1992), a theoretical model suggests that on a common soil, plant-induced negative feedbacks lead to convergence of productivity even for plants and plots differing widely in their traits and rates of N cycling, respectively (Tateno and Chapin 1997).

To address these issues we examined variation in biomass, ANPP, leaf area index (LAI), litter N cycling, and net $\mathrm{N}$ mineralization rates among a set of savanna plots in Minnesota, USA, that range widely in relative dominance by grasses and trees. Oak savannas and woodlands were once widespread in central North America, occurring primarily as an ecotonal band of varying width $(100-500 \mathrm{~km})$ between tallgrass prairie to the west and temperate deciduous forest to the east (Nuzzo 1986). Although innate site properties in part influenced the distribution and abundance of grassland vs. woodland communities, fire also played an integral role as a disturbance that modulated community composition and ecosystem properties (Kucera and Koelling 1964, Nuzzo 1986, Scholes and Archer 1997). Fire plays a similarly important role in open woodland ecosystems in Australia, Africa and several other parts of the world (Scholes and Archer 1997). Our study compares ANPP, biomass, and $\mathrm{N}$ cycling across a woodland-grassland continuum that developed in part due to $32 \mathrm{yr}$ of differential fire regimes. The experiment is located at the Cedar Creek Natural History Area in east central Minnesota, USA. Fire frequencies ranged from almost annual burning to complete fire protection (mean fire return intervals for burned plots vary from 1.2 to $8.7 \mathrm{yr}$ ), approximating or exceeding the historic range of presettlement fire frequencies in the region.

Variation in fire regime has resulted in unburned plots succeeding towards woodlands and frequently burned plots towards grasslands (Peterson and Reich 2001). Thus, our comparison of tree- and grass-dominated communities can not easily separate differences in ecosystem processes due to vegetation type from those due to different experimental disturbance regimes. Although this complicates the interpretation of patterns, such a comparison is logical, important, and natural (since grasslands naturally burn more frequently than woodlands). Moreover, since the association of percentage of tree canopy cover with fire frequency is only partial, we are able to some degree to evaluate the individual effects of each on ecosystem properties and processes. Among the many differences between grasses and trees, differences in canopy and root system properties are likely important in determining not only biogeographical distribution patterns but also the functioning of mixed tree-grass communities (Jackson et al. 1996, Scholes and Archer 1997, Blair et al. 1998, Mooney et al. 2000). These differences have been shown to influence the outcome of tree-grass competition (Gordon et al. 1989, Belsky 1994, Davis et al. 1998, Mitchell et al. 1999b), but their collective impact on productivity is less well known.

In examining productivity and $\mathrm{N}$ cycling in these savanna plots, we addressed the following questions: (1) What are the combined effects of fire history and vegetation type on ANPP, canopy N, litterfall N, soil $\mathrm{N}$ mineralization, and their relationships? If there is variation in rates of soil $\mathrm{N}$ cycling along the tree-grass/ fire continuum, does this relate to canopy or litter N? Do grass- and tree-dominated communities on similar soils and climate differ in biomass, productivity, and $\mathrm{N}$ cycling? If so, what are the causes? (2) If ANPP is greater in woody- than grass-dominated ecosystems, as we hypothesize, is it because of greater $\mathrm{N}$ capital or supply, greater efficiency of use of $\mathrm{N}$, or different allocation of productivity to ANPP vs. belowground NPP? (3) Are total fine root biomass, and/or the proportional distribution of fine biomass to roots vs. foliage, greater in grass-dominated than tree-dominated communities?

\section{Hypotheses}

In addressing these questions we tested the following five general hypotheses and a number of related questions.

Hypothesis \#1. Productivity and N cycling rates will be negatively related to fire frequency.-Both direct and indirect effects of fire should "push" the ecosystem in the same direction: frequent fire should depress the $\mathrm{N}$ cycle, due to $\mathrm{N}$ losses from the ecosystem (Ojima et al. 1994, Blair 1997) and grass dominance should also depress the $\mathrm{C}$ and $\mathrm{N}$ cycles (see hypotheses below).

Hypothesis \#2. ANPP will be positively related to the proportional dominance by trees.-If this is true, it may be because (a) trees dominate on intrinsically better quality sites (as more productive species dominate on better soils, e.g., Pastor et al. 1984), (b) trees make site-soil quality better via feedback processes (Binkley 1995), or (c) productivity is greater in woodythan grass-dominated ecosystems even on comparable sites.

Hypothesis \#3. Grass-dominated stands will have a greater root biomass, root productivity and proportional distribution of biomass and productivity belowground than tree-dominated stands.-Grasslands have often been reported to be more root centric in their biomass allocation and distribution than forests (Jackson et al. 1996), but surprisingly little information is 
TABLE 1. Fire frequency history, canopy structure, and biomass of study plots in 1995 .

\begin{tabular}{rcccc}
\hline \hline Plot & $\begin{array}{c}\text { Fire frequency } \\
\text { (fires/yr) }\end{array}$ & $\begin{array}{c}\text { Tree density } \\
\text { (trees/ha) }\end{array}$ & $\begin{array}{c}\text { Tree } \\
\text { basal area } \\
\left(\mathrm{m}^{2} / \mathrm{ha}\right)\end{array}$ & $\begin{array}{c}\text { Aboveground } \\
\text { tree biomass } \\
(\mathrm{Mg} / \mathrm{ha})\end{array}$ \\
\hline 4 & 0.81 & 69 & 6.5 & 26.3 \\
24 & 0.81 & 91 & 5.4 & 15.0 \\
3 & 0.78 & 203 & 9.2 & 36.8 \\
6 & 0.65 & 219 & 13.2 & 58.9 \\
1 & 0.49 & 99 & 6.8 & 25.7 \\
5 & 0.47 & 37 & 2.2 & 4.8 \\
16 & 0.48 & 104 & 9.9 & 47.4 \\
8 & 0.40 & 261 & 14.2 & 65.6 \\
901 & 0.40 & 309 & 7.7 & 27.1 \\
902 & 0.40 & 357 & 11.7 & 46.2 \\
7 & 0.36 & 192 & 11.9 & 57.8 \\
11 & 0.14 & 48 & 5.4 & 49.5 \\
13 & 0.14 & 109 & 9.7 & 17.0 \\
903 & 0.13 & 136 & 5.6 & 68.0 \\
904 & 0.13 & 453 & 15.2 & 84.5 \\
9 & 0 & 229 & 13.7 & 83.8 \\
905 & 0 & 347 & 16.4 & 118.6 \\
10 & 0 & 261 & 17.4 & 18.6 \\
18 & 0 & 552 & 22.7 & \\
15 & 0 & 435 & 27.4 & \\
\hline
\end{tabular}

Note: Tree density is given for stems $>10 \mathrm{~cm}$ dbh.

available on comparable soils and sites to evaluate this issue.

Hypothesis \#4. Differences in ANPP between woodyand grass-dominated communities will result from differences in both $N$ availability and $N$ use efficiency.The dominant grasses in tall grass prairie in Minnesota are warm season $\mathrm{C}_{4}$ grasses with high ecosystem-scale $\mathrm{N}$ use efficiency (NUE, assessed as ANPP per net $\mathrm{N}$ mineralization or the inverse of tissue $\mathrm{N}$ concentration; Vitousek 1982, Wedin and Tilman 1990, Knapp et al. 1998) and higher leaf photosynthetic $\mathrm{N}$ use efficiency than herbaceous or woody competitors (Turner and Knapp 1996, Long 1999). If ANPP is greater in treethan grass-dominated stands growing on similar soils (hypotheses $2 \mathrm{~b}$ and $2 \mathrm{c}$ above), they must either have (a) higher NUE (defined as ANPP per N supply) than the grasslands, which is inconsistent with the known high NUE of the dominant grasses; (b) a greater annual $\mathrm{N}$ cycle and comparable NUE; (c) a much greater $\mathrm{N}$ cycle and only slightly lower NUE; or (d) a different proportion of a similar total productivity allocated to above- vs. below-ground productivity.

Hypothesis \#5. Differences in NUE lead to convergence of productivity despite divergence in $N$ cycling for communities along the fire frequency and woody dominance gradient.-This will test whether the Tateno-Chapin model (Tateno and Chapin 1997) is correct or whether positive feedbacks lead to divergence in both ANPP and N cycling among vegetation types (Pastor et al. 1984, Wedin and Tilman 1990).

\section{Methods}

\section{Study area}

The study was located at the Cedar Creek Natural History Area (hereafter Cedar Creek), a 2300-ha re- serve and NSF Long-Term Ecological Research Site on the Anoka Sand Plain in eastern Minnesota $\left(45^{\circ} 25^{\prime} \mathrm{N}\right.$, $\left.93^{\circ} 10^{\prime} \mathrm{W}\right)$. The terrain is relatively flat, with total relief of $<10 \mathrm{~m}$. Soils are infertile, excessively drained, fine to medium sands of the Sartell (Typic Udipsamment) and Zimmerman (Alfic Udipsamment) series (Grigal et al. 1974). The climate is humid continental, with warm summers and cold winters. Mean annual temperature is $6^{\circ} \mathrm{C}$, with mean daily temperatures ranging from $22^{\circ}$ in July to $-11.5^{\circ}$ in January. Mean annual precipitation is $79 \mathrm{~cm}$, with $64 \%$ of this total occurring during the active growing season (May-September).

\section{Burning program/experiment}

A prescribed burning experiment was initiated at Cedar Creek in 1964 to characterize responses to varying fire frequency and to restore and maintain oak savanna vegetation (Peterson and Reich 2001). An area of $\sim 300$ ha was divided into 19 management units of 2.4 to 30 ha and each was assigned a burn frequency treatment, ranging from nearly annual burns to complete fire exclusion (Table 1). All units were inhabited in mid-century by seminative woodland that had never been plowed but had likely been periodically grazed and experienced selective logging. Baseline vegetation data were not collected prior to the start of the prescribed fire program in 1964. A series of air photos taken between 1938 and 1964 show increasing total canopy cover resulting from expansion of tree crowns and ingrowth of new trees. There are no reliable fire records from this time period, but fire exclusion was the management objective and was apparently achieved. Prior to 1938 these stands likely burned periodically. In 1995 , most of the largest tree stems ranged from 50 to $130 \mathrm{yr}$ old. 
Prescribed burns were conducted in April or May, after the snow melted and before leaves appeared on the oaks. Most burns were ignited using a strip headfire technique. Typical burning conditions included air temperatures of $15^{\circ} \mathrm{C}$ to $25^{\circ} \mathrm{C}$, relative humidity of $25 \%$ to $45 \%$ and winds $<20 \mathrm{kph}$. Fuels varied with stand physiognomy and number of years between burns. Fire behavior varied with weather conditions and fuel loads, but fires were generally of low intensity, with mean flame lengths $<1 \mathrm{~m}$ (P. Reich, personal observation).

We defined fire frequency (Table 1) over the period of time plots have been part of fire frequency treatments (number of fires/[1996 - year of first fire]+1) or over the most recent eight-year period if fire treatments began during that period (number of fires/ 8 if first fire was later than 1987). For 16 plots, fire frequency is thus defined over the entire 32-yr experiment, while for four plots it is defined over the most recent eightyear period. Since the same fire regime over $32 \mathrm{yr}$ can have different impacts than over eight years (i.e., cumulative number of fires could have different effect than the fire return interval) we also explored alternate definitions, such as total number of fires in the past 8 , 12 , or 32 yr. These differences in definition did not alter the results in substantial ways.

\section{Vegetation}

After $32 \mathrm{yr}$ of variable fire frequency, the communities had diverged considerably in structure and composition. The unburned communities were increasingly dominated by woody plants whereas the frequently burned communities were increasingly dominated by herbaceous plants, especially grasses (Peterson 1998). Two oak species (northern pin oak, Quercus ellipsoidalis E. J. Hill, and bur oak, Quercus macrocarpa Michx.) represented the vast majority of the tree strata, especially in the burned plots. The relative importance of bur oak within the tree community increased with fire frequency (Peterson and Reich 2001). Important shrubs and herbaceous species included Corylus americana, Rhus glabra, Prunus virginiana, Andropogon gerardii, Schizachyrium scoparius, Sorghastrum nutans, Poa pratensis, Carex pensylvanica, Parthenocissus vitacea, Amphicarpa bracteata, and Rhus radicans.

\section{Data collection and analysis}

Permanent 0.375 -ha plots $(50 \times 75 \mathrm{~m})$ were established in the experimental units. Each plot consisted of four parallel $50-\mathrm{m}$ sampling transects placed $25 \mathrm{~m}$ apart. Sample points were placed at $10-\mathrm{m}$ intervals along each transect for a total of 24 sample points per plot. A total of 20 such plots were sampled for this study in 1995 in areas ranging from open oak savanna to closed forest and representing a fire frequency gradient from unburned to fires in four out of five years (Table 1). Soils are relatively homogeneous among plots (Grigal et al. 1974).

Total biomass was estimated from measurements of root and aboveground biomass. Fine ( $<3 \mathrm{~mm}$ diameter) and coarse roots (all others) were sampled in mid-summer from 0-30 cm depth in the eight most central subplots within each plot, in 14 of the 20 plots (due to labor constraints). Fine roots made up $95 \%$ of total root biomass on average across all plots. The biomass distribution with depth was assessed twice in each plot (in spring and summer). In both seasons, the $0-30 \mathrm{~cm}$ zone held a mean of $83 \%$ of the fine roots present in the top $1 \mathrm{~m}$ (across all plots, with no differences noted). This value was used to estimate mid-summer fine root biomass to $1 \mathrm{~m}$ depth. A survey of permanently marked trees in 1995 recorded species, status (alive, dead, snag, fallen), and diameter at breast height ( $\mathrm{dbh}$, if $\mathrm{dbh}>5$ $\mathrm{cm}$ ) for each stem within the plot boundaries. Littertraps (eight per plot) were placed randomly throughout each plot. Herbaceous and shrub biomass were estimated for each plot from light interception measurement using calibration curves relating light interception to biomass.

Annual aboveground net primary production (ANPP) was assumed to be the sum of herbaceous and woody plant leaf biomass (which turns over annually), combined with estimates of annual new wood production. Tree wood production was estimated using the combination of $10-\mathrm{yr}$ tree increment cores and wood biomass. A subsample of trees on each plot were sampled for 10yr radial growth based on increment coring (total of 185 northern pin oak and 160 bur oak trees, respectively). From these data we developed plot-specific regression relationships ( $r^{2}>0.97$ on average) between dbh in 1995 and 1985, which were then applied to all live trees on each plot in 1995 to estimate dbh in 1985. In 1992, 1224 oak trees were measured for both height and diameter. An equation was derived from these data to predict height for trees in 1985 or $1995(\ln [$ height $]=-0.597$ $+(0.640 \times \ln [\mathrm{dbh}])+(0.371 \times \ln [$ basal area $]) ; r^{2}=$ $0.58)$. From these dbh and height values we estimated individual tree woody biomass values (based on allometric equations from Alemdag 1983) which were aggregated to the whole plot scale for both years, and we estimated tree annual wood NPP as the annual mean of the 10 -yr increment. We did not include wood production of trees that died between 1985 and 1995 because it was likely negligible and difficult to estimate accurately.

Green leaf (measured in midsummer) and litterfall leaf areas and masses, and $\mathrm{N}$ concentrations, were measured in bur and northern pin oak trees in all plots to estimate specific leaf area (SLA), canopy N, litterfall $\mathrm{N}$, and $\mathrm{N}$ resorption rates. Shrub and herbaceous $\mathrm{N}$ samples were obtained from clipped subplots. Tree LAI was estimated (after converting mass to area based on mean SLA) based on both the litterfall method (used in this report) and on allometric relationships (Alemdag 1983). These two estimates were in good agreement and did not differ significantly $(P>0.10)$ from the $1: 1$ line. Tissue $\mathrm{N}$ concentrations were analyzed at the Uni- 
versity of Minnesota Plant Analytical Laboratory. Wood N concentrations were not measured, but were assumed to equal $0.18 \%$ (Kramer and Kozlowski 1979).

Soil net $\mathrm{N}$ mineralization rates were measured in 1995 for the $0-15 \mathrm{~cm}$ depth horizon using in situ incubations for the eight most central subplots within each plot over five incubation periods (30-45 d each) from April 10 to October 15. We used a modified semiopen core method for in situ incubation of samples (Wedin and Tilman 1990). At the beginning of each incubation period, a $2.5-\mathrm{cm}$ diameter by $15 \mathrm{~cm}$ long soil core was removed from each sample point and returned to the lab for processing. A paired core was located within $10 \mathrm{~cm}$ of the "initial" sample by pounding a sharpened tube of $2.5 \mathrm{~cm}$ diameter PVC pipe into the ground to a depth of $15 \mathrm{~cm}$. The top of the pipe was covered with a rubber cork to prevent water flow through the soil column. Air holes between the soil surface and the cork facilitated ventilation of the sample during incubation. At the end of the incubation period, the PVC cores were extracted and returned to the laboratory for processing. Samples were refrigerated at $4^{\circ} \mathrm{C}$ for up to $48 \mathrm{~h}$ prior to processing. Soil nitrogen was extracted from 20-25 g of field-moist soil in $50 \mathrm{~mL}$ of $1 \mathrm{~mol} / \mathrm{L} \mathrm{KCl}$ solution and measured colorimetrically on an Alpkem autoanalyzer (Alpkem, College Station, Texas, USA) for $\mathrm{N}_{\text {as }} \mathrm{NO}_{3}{ }^{-}$and $\mathrm{NH}_{4}{ }^{+}$. Nitrification and $\mathrm{N}$ mineralization rates were calculated as the difference in $\mathrm{NO}_{3}{ }^{-}$and in total $\mathrm{N}\left(\mathrm{NO}_{3}{ }^{-}+\mathrm{NH}_{4}{ }^{+}\right)$, respectively, between the incubated and initial soil samples. Annual rates per subplot were estimated as the sum of the values for the five incubation periods. These were averaged to provide the plot measures used in this study. Mass-based $\mathrm{N}$ mineralization rates were converted to area-based measurements, based on a regression relationship between total soil carbon (percentage) and soil bulk density.

Several alternative measures of $\mathrm{N}$ residence time, productivity, and use efficiency were examined and compared. N use efficiency has alternatively (Vitousek 1982, Pastor et al. 1984, Gower and Son 1992) been defined as (1) the ratio of biomass produced per unit $\mathrm{N}$ lost (i.e., the inverse of litter $\mathrm{N}$ concentration); (2) the ratio of aboveground productivity and $\mathrm{N}$ loss in litterfall (ANPP/litterfall $\mathrm{N}$ in the present study); (3) productivity per annual $\mathrm{N}$ availability, uptake, or $\mathrm{N}$ mineralization. We also estimate the mean residence time (MRT) of $\mathrm{N}$ in the living plant community, focusing on fine roots, using the definition of Berendse and Aerts (1987) and a N-budgeting approach to estimating MRT (cf. Aber et al. 1985, Nadelhoffer et al. 1985) wherein MRT of $\mathrm{N}$ is defined as the total standing pool of $\mathrm{N}$ in the plant community (foliage, new or total woody, roots) divided by the annual $\mathrm{N}$ availability, which is calculated as

$$
\mathrm{N}_{\mathrm{a}}=\mathrm{N}_{\mathrm{m}}+\mathrm{N}_{\mathrm{p}}-\mathrm{N}_{1}
$$

where $\mathrm{N}_{\mathrm{a}}$ is $\mathrm{N}$ availability, $\mathrm{N}_{\mathrm{m}}$ is measured minerali- zation, $\mathrm{N}_{\mathrm{p}}$ is wet plus dry input, estimated at $\sim 10$ $\mathrm{kg} \cdot \mathrm{ha}^{-1} \cdot \mathrm{yr}^{-1}$ for Cedar Creek (modified from Wedin and Tilman 1995 to account for underestimates of dry deposition) and $\mathrm{N}_{1}$ is leaching loss below the rooting zone, which we assumed to be negligible based on prior studies at Cedar Creek (Wedin and Tilman 1995). Using the same logic, the MRT of $\mathrm{N}$ in fine roots was estimated by dividing the standing $\mathrm{N}$ pools in fine roots by the annual allocation of $\mathrm{N}$ to fine roots, which was calculated by subtracting the annual aboveground allocation of $\mathrm{N}$ (to new woody biomass and to foliage) from the total $\mathrm{N}$ availability.

The MRT of $\mathrm{N}$ in fine roots was assumed to equal the fine root life-span, based on the assumption of negligible $\mathrm{N}$ resorption from fine roots prior to senescence. Whether fine roots typically resorb $\mathrm{N}$ during senescence is remarkably poorly documented, but the most comprehensive and direct studies found no resorption (Nambiar 1987, Aerts 1992). Hence, root turnover rates were assumed to equal the inverse of root N MRT (Aber et al. 1985, Nadelhoffer et al. 1985, Aerts 1990) and root NPP to be root biomass divided by the MRT. A recent soil methods paper (Fahey et al. 1999) evaluated several different approaches to estimating root turnover rates and belowground NPP (BNPP), including sequential and maximum-minimum coring, ingrowth cores, $\mathrm{N}$ budgets, and minirhizotrons. They concluded that all methods rely on untested assumptions and have associated uncertainties, and recommended the latter two as particularly promising.

Several measures of proportional tree dominance were available for use, including tree basal area, proportion of total biomass, or total LAI contributed by trees. Instead, we decided to use percentage of woody canopy cover for two reasons. First, it was measured independently of other measures of tree biomass and productivity in this study and, second, it is probably the most common measure used to define the proportional dominance by trees and grasses in woodlands and savannas globally (Scholes and Archer 1997). To evaluate the relative dominance by woody vs. herbaceous species independently from measures of woody biomass, we measured the percentage of canopy openness at all 24 sample points per plot in late summer 1995 using the LAI-2000 Plant Canopy Analyzer (LiCor, Lincoln, Nebraska, USA). This sensor provided a weighted proportion of open sky visible above a sample point. Readings were taken under conditions of uniform, diffuse light (twilight hours, or cloudy days) using a $270^{\circ}$ lens cap $\left(90^{\circ}\right.$ occluded), and were paired with readings from another sensor operating continuously in a nearby open field. Two readings (subsequently averaged) were taken at each sample point below the herbaceous layer, above the herbaceous layer but below the shrub layer, and above the shrub layer but below the tree strata. These provided measures of the percentage of tree canopy openness (just trees) and the percentage of woody canopy openness (\%WCO) 
that included the shrub and tree layers. Subsequently all 24 of these measures were averaged for each plot. The mean \%WCO per plot was strongly correlated with tree basal area/ha $\left(r^{2}=0.95\right.$; Peterson 1998) among all 20 stands, demonstrating its utility as a measure of tree dominance.

We used light interception data from the same 24 sample points per plot to estimate herbaceous and shrub biomass, using independent calibrations derived from a regression of clipped biomass on 47 plots in savanna and simultaneous measures of the percentage of canopy openness (\%CO). For these 47 plots, we used \%CO readings below vs. above the herbaceous layer and compared them to the clipped biomass. In that data set, the two variables were linearly related $\left(r^{2}=0.59\right)$. However, since we averaged the light interception measurements for 24 subplots per each 0.375-ha savanna plot to estimate the biomass of the herbaceous and shrub layers, we also assessed the predictions of biomass made by averaging multiple light interception measurements within a plot. To do this we used 12 plots of aggregated measurements (6-28 subplots per plot, 224 in total) from a wider survey of both \% CO and biomass in various savanna and grassland plots at Cedar Creek (data not shown). In this survey, mean biomass was highly correlated $\left(r^{2}=0.94\right)$ with mean $\% \mathrm{CO}$, and the relationship between predicted and observed biomass had a slope of 1.01 (not significantly different than 1) and an intercept of $-1.7 \mathrm{~g} / \mathrm{m}^{2}$ (not significantly different than zero). Hence we conclude that the light interception technique provides a reasonable estimate of individual subplot biomass and a better estimate of mean whole plot biomass. During the light interception censusing, some tall shrubs were occasionally located in the tree layer and some short shrubs in the herbaceous layer, so the biomass attributed to a given life form may include some small contribution from another type. For tall shrubs and trees this is immaterial in any case, since they play a similar functional role in the ecosystem.

The proportion of the estimated combined herb plus shrub biomass attributed to shrubs vs. herbaceous vegetation was calculated for each subplot based on the proportion of their combined canopy closure (i.e., diminished canopy openness) attributed to each class, taken from the measurements made above vs. below each layer (i.e., difference in \% CO due to shrubs or herbs/difference in \% CO due to shrubs plus herbs). Shrub biomass was also estimated independently for subsets of the plots using both direct sampling and from visual percentage cover estimates and published calibration curves converting percentage cover to biomass. These various estimates did not differ substantially, and only the more numerous indirect light interceptionbased estimates are used in this study. In this paper we present data for woody plants, combining tree and shrub layer biomass values. In most cases, the contribution of shrubs to these values is low.

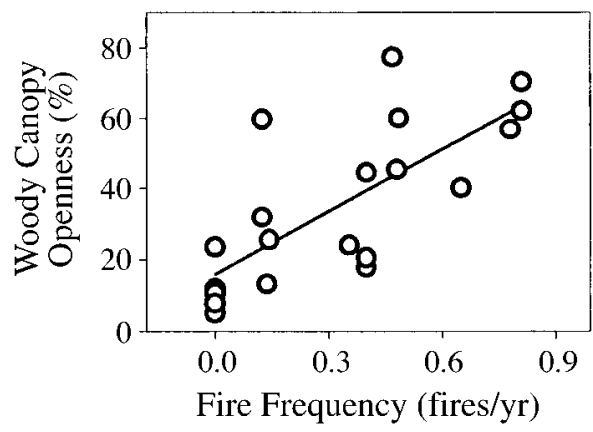

FIG. 1. Percentage of woody canopy openness vs. fire frequency (mean number of fires/yr) for 20 savanna and woodland stands at Cedar Creek Natural History Area in east central Minnesota, USA $\left(P<0.001, r^{2}=0.54\right)$.

We used linear and nonlinear regression to assess the relationships among the variables and factors of interest, in part because many of the relationships were presumed to be functional to some degree. We also used regression rather than correlation because it allows nonlinear relationships to be characterized, and we generally had no a priori notion of the shape of such relationships. Regressions were shown as linear unless nonlinear fits resulted in substantial improvements in homoscedasticity or fit. In that case, the nonlinear equation that had the best fit and residual distribution was used, but we do not imply these represent biologically relevant functions.

\section{RESUlTS}

Repeated burning increased the percentage of woody canopy openness (\%WCO; Fig. 1) by increasing tree mortality and limiting recruitment. However, only about half of the variation in \% WCO is explained by fire frequency, with the remainder a result of differing vegetation states at the beginning of the fire frequency experiment and other causes. Thus, plots differing in $\% \mathrm{WCO}$ occur in similar fire frequency treatments (e.g., at fire frequency of 0.4 to 0.6 in Fig. 1), and plots differing in fire frequency can have similar \%WCO.

Aboveground biomass, most of which was wood, declined sharply and nonlinearly with increasing fire frequency and decreasing tree canopy dominance (Fig. 2 ). Total foliage biomass (woody plus herbaceous) declined markedly along the same gradients (Fig. 2). In contrast to foliage biomass, fine root biomass had the opposite pattern, being greatest in the frequently burned, herbaceous-dominated stands (Fig. 2). As a result of the opposite patterns of foliage vs. fine root biomass in relation to \% WCO or fire frequency, the grass-dominated stands had a greater proportion of total fine tissue biomass in fine roots (as much as 75\%), whereas tree-dominated plots had roughly $40-60 \%$ of that fraction in fine roots (Fig. 2). Thus, grass-dominated communities had lower total biomass and canopy mass than tree-dominated ones, but greater fine root 


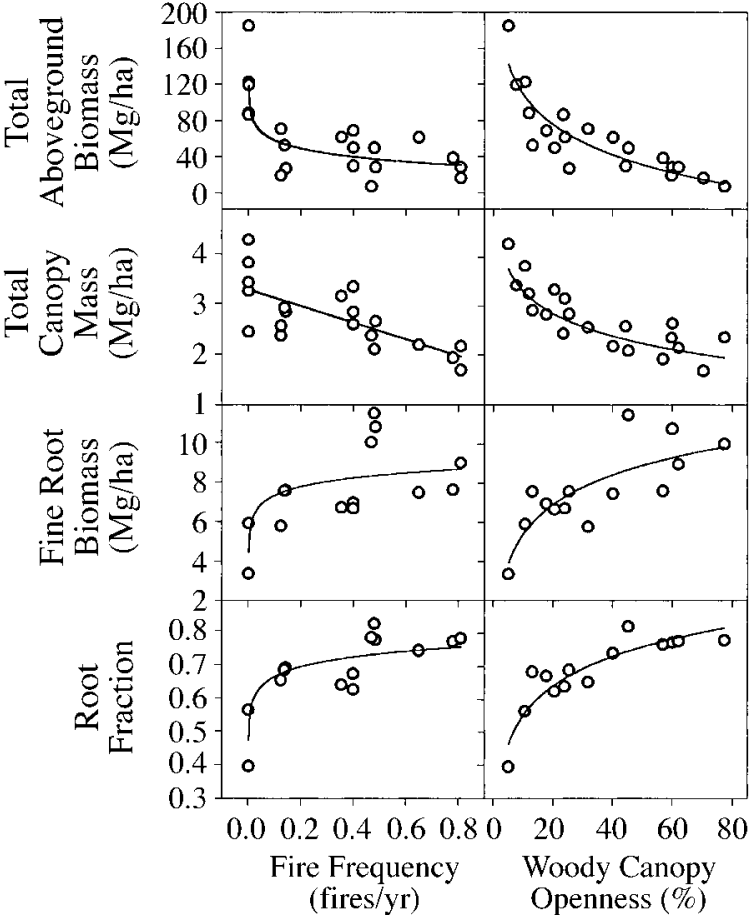

FIG. 2. Total aboveground biomass, total canopy foliage biomass, fine root biomass (0-1 $\mathrm{m}$ depth), and fine root biomass as a fraction of total fine tissue biomass (fine roots/[fine root + foliage]) for 20 savanna and woodland stands, in relation to fire frequency $\left(r^{2}=0.66,0.52,0.44\right.$, and 0.71 , respectively) and percentage of woody canopy openness $\left(r^{2}=\right.$ $0.78,0.79,0.63$, and 0.83 , respectively). All relationships are significant at $P<0.001$.

mass and fractional distribution of fine biomass in roots.

The absolute and relative contribution to aboveground net primary production (ANPP) of differing functional groups varied across the vegetation typefire frequency gradient. Woody plant ANPP declined from as great as $12 \mathrm{Mg} \cdot \mathrm{ha}^{-1} \cdot \mathrm{yr}^{-1}$ in the unburned, treedominated plots to $<1 \mathrm{Mg} \cdot \mathrm{ha}^{-1} \cdot \mathrm{yr}^{-1}$ in the frequently burned plots. Both components of woody plant ANPP, foliage and wood NPP, decreased with increasing fire frequency $\left(r^{2}>0.56\right)$ and, not surprisingly, \%WCO $\left(r^{2}\right.$ $>0.76$; Fig. 3). In contrast herbaceous ANPP increased from 0.1 to $2.0 \mathrm{Mg} \cdot \mathrm{ha}^{-1} \cdot \mathrm{yr}^{-1}$ across the same gradients. Herbaceous ANPP linearly increased with \%WCO $\left(r^{2}\right.$ $=0.95)$, and was less closely related to fire frequency $\left(r^{2}=0.56\right)$. The tight scaling with \%WCO suggests a key role for light availability in controlling grass ANPP.

With decreasing fire frequency and increasing woody dominance, the increase in woody plant foliage biomass (from 0.2 to $3.5 \mathrm{Mg} \cdot \mathrm{ha}^{-1} \cdot \mathrm{yr}^{-1}$ ) more than offset the decrease in herbaceous biomass (from 2.0 to 0.1 $\mathrm{Mg} \cdot \mathrm{ha}^{-1} \cdot \mathrm{yr}^{-1}$ ), resulting in negative relationships between total (i.e., ecosystem) foliage biomass and $\%$ WCO or fire frequency (Fig. 2). Similarly, since the gradient in ANPP was much larger for the tree than herbaceous component of the ecosystem, total ANPP was highest in the unburned, tree-dominated stands and decreased with fire frequency $\left(r^{2}=0.59\right)$ and $\% \mathrm{WCO}$ $\left(r^{2}=0.83\right.$; Fig. 3$)$. Several other ecosystem-scale parameters also were strongly related to the fire frequency and \%WCO gradients. Total leaf area index (LAI), total canopy $\mathrm{N}$, annual litterfall $\mathrm{N}$ cycling, and soil net $\mathrm{N}$ mineralization all decreased, usually nonlinearly, with increasing \% WCO and fire frequency (Fig. 4). These four variables were equally or more closely related to $\% \mathrm{WCO}$ (mean $r^{2}=0.78$ ) than to fire frequency (mean $\left.r^{2}=0.58\right)$. Soil net nitrification rates were also negatively related to both fire frequency and \%WCO (data not shown). Net nitrification as a fraction of net $\mathrm{N}$ mineralization was greater in grass-dominated frequently burned communities (mean of $60 \%$ ) than in unburned woody-dominated communities (mean of $40 \%$ ).

Total ANPP was strongly related to LAI $\left(r^{2}=0.87\right)$ and three measures of ecosystem $\mathrm{N}$ : total canopy $\mathrm{N}$ content $\left(r^{2}=0.88\right)$, annual $\mathrm{N}$ cycling in aboveground litter $\left(r^{2}=0.70\right)$, and annual net $\mathrm{N}$ mineralization rates $\left(r^{2}=0.79\right.$; Fig. 5). All three measures of ecosystem $\mathrm{N}$ also were strongly correlated with each other (Fig. 5). Since all foliage in these communities turns over an-

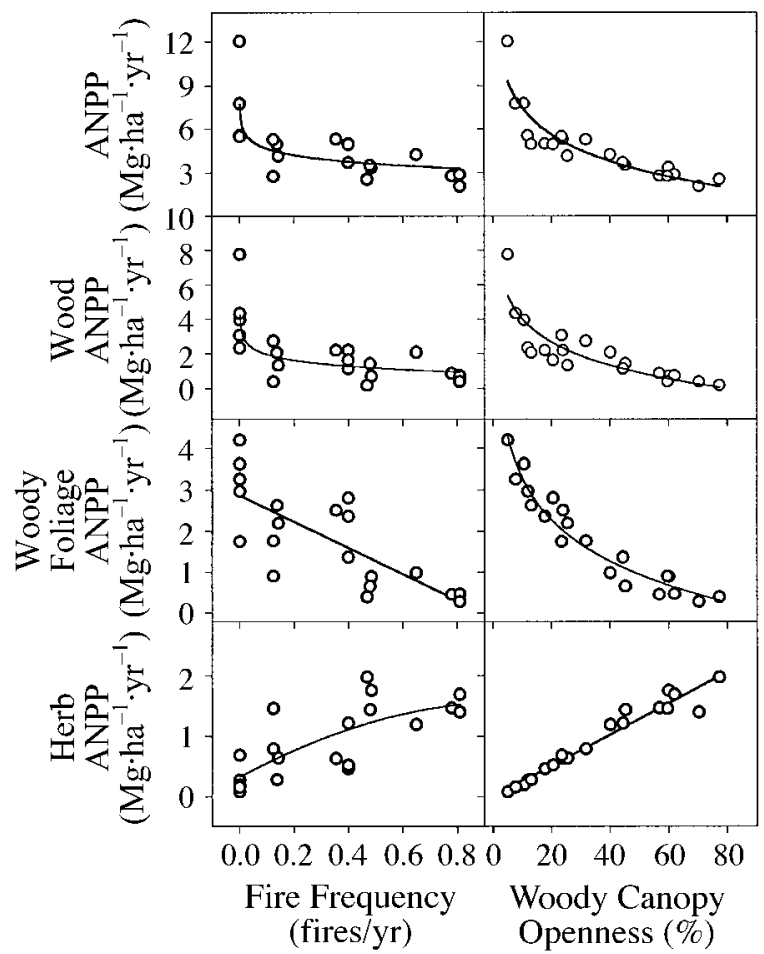

FIG. 3. Total aboveground net primary production (ANPP) and its components, aboveground wood NPP, woody foliage NPP, and herbaceous ANPP, in relation to fire frequency ( $r^{2}=0.59,0.57,0.58$, and 0.56 , respectively) and percentage of woody canopy openness $\left(r^{2}=0.83,0.76,0.94\right.$, and 0.95 , respectively) for 20 woodland and savanna stands. All relationships are significant at $P<0.001$. 


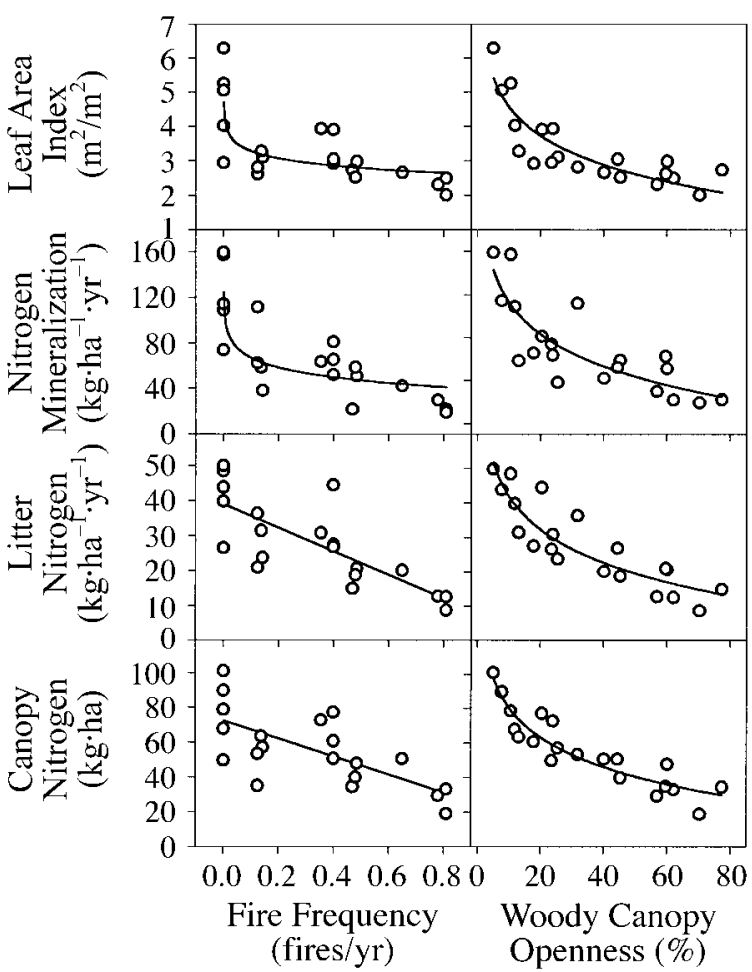

FIG. 4. Total ecosystem leaf area index, annual net $\mathrm{N}$ mineralization rate, total annual aboveground litter $\mathrm{N}$, and total canopy $\mathrm{N}$, in relation to fire frequency $\left(r^{2}=0.57,0.65\right.$, 0.63 , and 0.48 , respectively) and percentage of woody canopy openness ( $r^{2}=0.77,0.69,0.80$, and 0.86 , respectively) for 20 woodland and savanna stands. All relationships are significant at $P<0.001$.

nually, differences between woody- and grass-dominated plots in canopy $\mathrm{N}$ pools and annual aboveground $\mathrm{N}$ cycling could result from either differing $\mathrm{N}$ concentrations (in green and senesced foliage, respectively), the total amount of foliage, or both. These differences in aboveground $\mathrm{N}$ pools and turnover rates were largely driven by the differences among plots in the amount of foliage (see Fig. 2), but there were also differences in mean tissue $\mathrm{N}$ concentration that reflect both the different composition and the different $\mathrm{N}$ availability across the forest-grassland continuum.

Total canopy $\mathrm{N}$ concentration and fine root $\mathrm{N}$ concentration decreased with increasing fire frequency $\left(r^{2}\right.$ $=0.36$ and 0.41$)$ and \%WCO $\left(r^{2}=0.77\right.$ and 0.67), and increased with annual $\mathrm{N}$ mineralization rates $\left(r^{2}=\right.$ 0.57 and 0.51 ; Fig. 6). Moreover, variation in tissue $\mathrm{N}$ concentration across the $\mathrm{N}$ mineralization gradient differed among functional groups. Green leaf oak N concentration (which averaged $22.4 \mathrm{mg} / \mathrm{g}$ ) did not differ significantly across the fire frequency gradient, nor in relation to either annual net $\mathrm{N}$ mineralization or $\%$ WCO. In contrast, mean herbaceous foliage $\mathrm{N}$ concentration declined substantially with increasing grass dominance (data not shown), largely because woodland understory forbs (characterized by innately higher tis- sue $\mathrm{N}$ concentration) are replaced by grasses in the frequently burned savanna plots. Thus, the overall gradient in total canopy $\mathrm{N}$ concentration (in Fig. 6) largely reflects variation in composition, with species with higher $\mathrm{N}$ concentration (oaks and woodland forbs) dominating at low \% WCO and species with lower N concentration (grasses) dominating at the other end.

Although green leaf $\mathrm{N}$ concentration did not vary in oak across the $\mathrm{N}$ mineralization gradient, percentage of $\mathrm{N}$ resorption was greater for the oaks in the grassland dominated plots with lower $\mathrm{N}$ mineralization rates $(\sim 70 \%)$ than in the wooded plots with higher $\mathrm{N}$ mineralization ( $\sim 50 \%$; Fig. 7$)$. The greater percentage of $\mathrm{N}$ resorption in the open savanna plots resulted in significantly lower oak litter $\mathrm{N}$ concentration and higher $\mathrm{C}: \mathrm{N}$ ratios in these frequently burned plots with lower net $\mathrm{N}$ mineralization rates. These differences were substantial-oak litter $\mathrm{N}$ averaged $9-10 \mathrm{mg} / \mathrm{g}$ in frequently burned and 13-14 mg/g in the unburned plots.

Herbaceous litter $\mathrm{N}$ concentration and $\mathrm{C}: \mathrm{N}$ ratios varied even more strikingly across the $\mathrm{N}$ mineralization gradient (Fig. 7). Herbaceous litter $\mathrm{N}$ concentration varied twofold across the fire frequency gradient and threefold across either the \% WCO or $\mathrm{N}$ mineralization gradients. This does not indicate a huge gradient in litter $\mathrm{N}$ concentration within species, however, for the following reasons. These herbaceous values were derived from aggregate samples of the extant vegetation. Given that composition varies greatly across the fire frequency gradient (Peterson 1998) and that these species vary widely in their tissue $\mathrm{N}$ concentration, the observed gradient in herbaceous litter $\mathrm{N}$ concentration largely represents a compositional gradient, not a shift in litter chemistry within species. The combination of differences in overall species composition and in litter quality of oaks resulted in a strong litter $\mathrm{C}: \mathrm{N}$ gradient with fire frequency or \%WCO, which, along with a parallel gradient in total litter quantity, has significant consequences for decomposition and $\mathrm{N}$ cycling.

Fine root MRT for N, and hence, estimated fine root longevity, varied sharply with fire frequency and $\%$ WCO (Fig. 8), increasing from $\sim 1$ yr to $4 \mathrm{yr}$ from unburned woodland plots to frequently burned open savanna plots. As a result of this variation in root turnover rates, estimated root NPP values were higher in woodland plots than in frequently burned open savanna plots, despite lower standing root biomass pools in the former. Fine root productivity was estimated to range from 2 to $9 \mathrm{Mg} \cdot \mathrm{ha}^{-1} \cdot \mathrm{yr}^{-1}$ across the tree/grass and fire frequency continuum. These estimated root NPP values were a similar proportion of total estimated NPP in all plots: there was no tendency for grass-dominated plots to have a greater (or lesser) proportion of NPP occurring belowground than for woody-dominated plots. As a result, total estimated NPP scaled with woody dominance and fire frequency much the same as did ANPP (Fig. 8).

Whether nitrogen use efficiency (NUE) was greater 


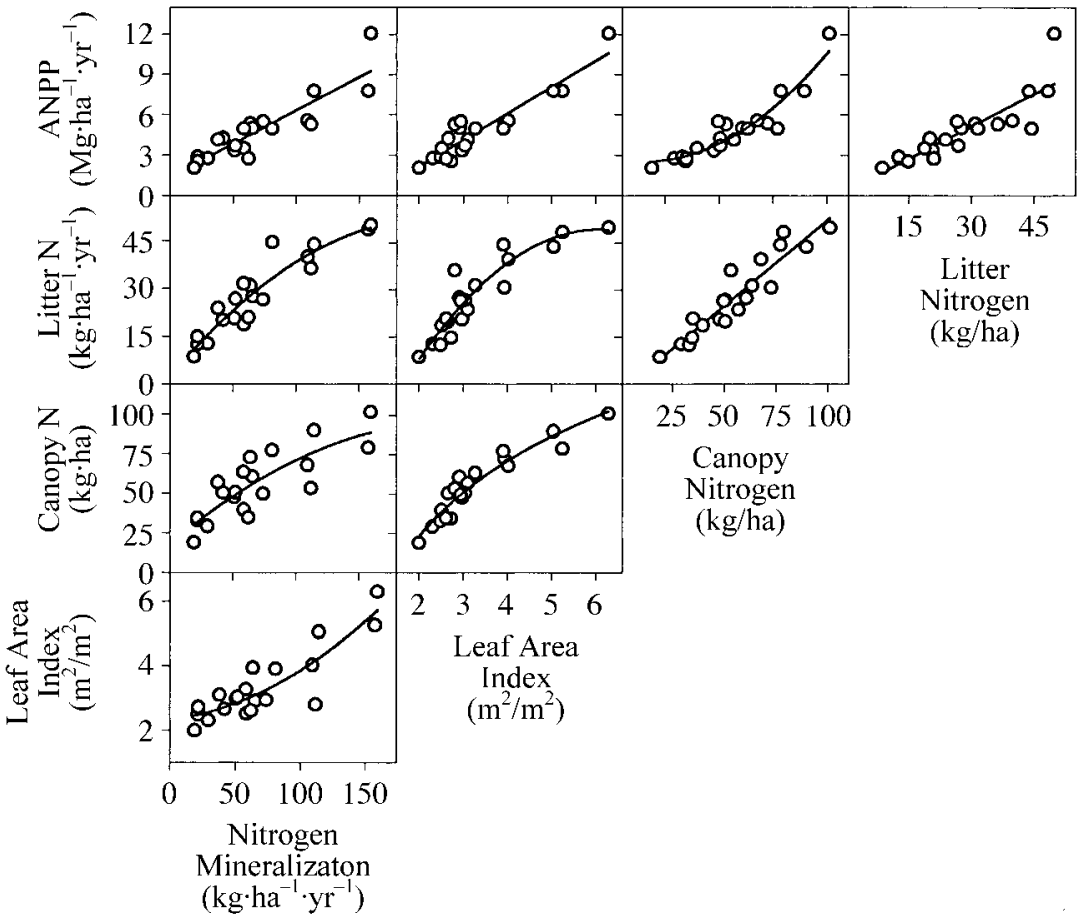

FIG. 5. Total ANPP in relation to annual net $\mathrm{N}$ mineralization rate $\left(r^{2}=0.79\right)$, leaf area index (LAI) $\left(r^{2}=0.87\right)$, total canopy $\mathrm{N}\left(r^{2}=0.88\right)$, and total annual aboveground litter $\mathrm{N}\left(r^{2}=0.70\right)$; total litter $\mathrm{N}$ in relation to net $\mathrm{N}$ mineralization rate $\left(r^{2}=0.87\right)$, LAI $\left(r^{2}=0.86\right)$, and total canopy $\mathrm{N}\left(r^{2}=0.87\right)$; total canopy $\mathrm{N}$ in relation to net $\mathrm{N}$ mineralization rate $\left(r^{2}\right.$ $=0.68)$ and LAI $\left(r^{2}=0.92\right)$; and LAI in relation to net $\mathrm{N}$ mineralization rate $\left(r^{2}=0.77\right)$. All relationships are significant at $P<0.001$.

in frequently burned grass-dominated than woodydominated communities depended on the definition used. Grass-dominated communities had greater ANPP per unit $\mathrm{N}$ mineralization (Fig. 9) and greater production per unit $\mathrm{N}$ loss if only leaves and fine litter are included (cf. Vitousek, 1982; i.e., inverse of data in Fig. 7). A similar, but weaker pattern occurs if NUE is defined as ANPP/annual litter $\mathrm{N}$ loss (data not shown), and no significant relationship exists for ANPP/annual N requirements (Fig. 9). NUE can also be decomposed into two parts (N productivity and MRT; Berendse and Aerts 1987). ANPP per standing
$\mathrm{N}$ crop (i.e., $\mathrm{N}$ productivity) had opposite patterns to the ANPP/N mineralization and inverse litterfall $\mathrm{N}$ concentration patterns (Fig. 9). Berendse and Aerts (1987) perspective on how to interpret these differing patterns would suggest that grass-dominated assemblages are more productive for a given level of soil $\mathrm{N}$ supply (high ANPP per $\mathrm{N}$ mineralization) because of their low overall $\mathrm{N}$ turnover rates, despite having low productivity per unit time for the pool of $\mathrm{N}$ in the living tissues.

Although frequently burned stands were dominated by grasses rather than trees, with the opposite pattern for unburned plots, the correlation was only partial
FIG. 6. Mean total canopy leaf N concentration and mean fine root $\mathrm{N}$ concentration, in relation to fire frequency $\left(r^{2}=0.36\right.$ and 0.41 , respectively), percentage woody canopy openness ( $r^{2}=0.77$ and 0.67 , respectively), and annual net $\mathrm{N}$ mineralization rates $\left(r^{2}=0.57\right.$ and 0.51 , respectively), for 20 woodland and savanna stands. All relationships were significant at $P<0.001$.

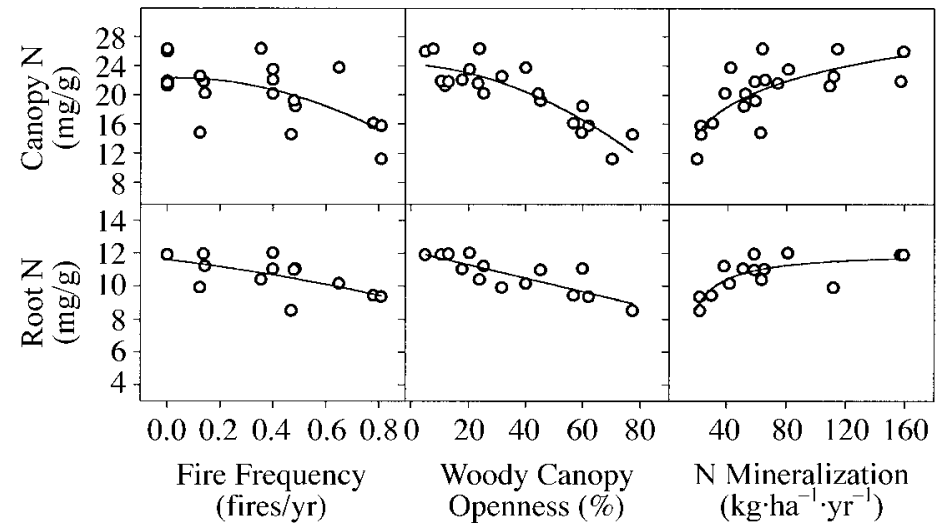




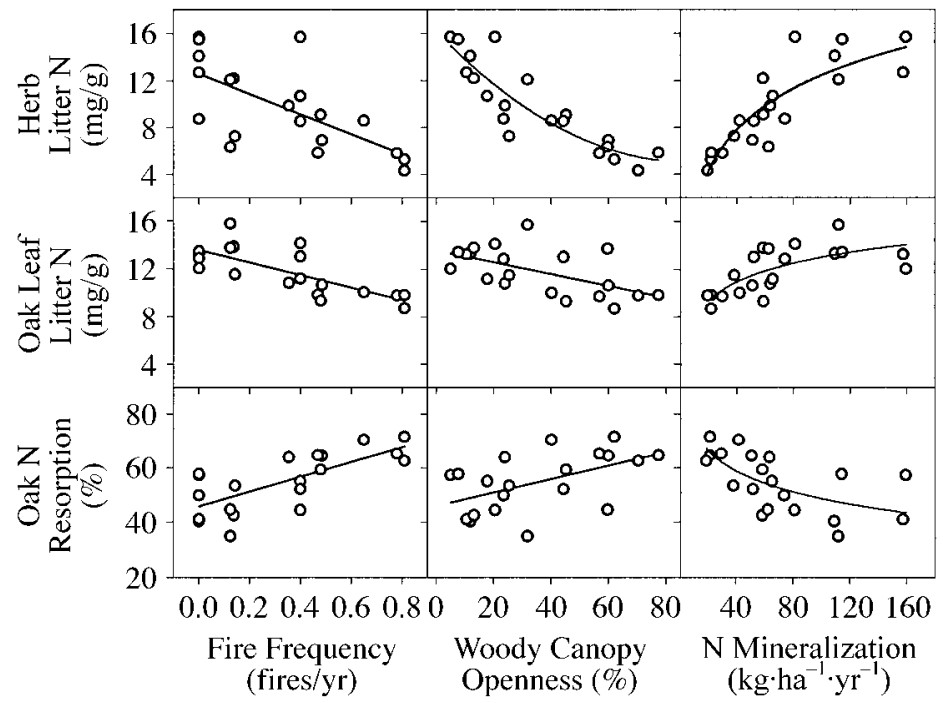

FIG. 7. Herbaceous litter $\mathrm{N}$ concentration, oak litter $\mathrm{N}$ concentration, and percentage of $\mathrm{N}$ resorption from senescing oak leaves, in relation to fire frequency $\left(r^{2}=0.45,0.58\right.$, and 0.53 , respectively), percentage of woody canopy openness $\left(r^{2}=0.79,0.34\right.$, and 0.27 , respectively), and annual net $\mathrm{N}$ mineralization rates $\left(r^{2}=0.75,0.52\right.$, and 0.43 , respectively) for 20 woodland and savanna stands. All relationships are significant at $P<0.05$.
(Fig. 1). Thus, we used two other approaches to provide some indication of the independent effects of fire frequency and \%WCO, and of their interaction. Using multiple regression analyses, key ecosystem variables measured in this study tended to be related to both $\% \mathrm{WCO}$ and fire frequency, or to \% WCO and an interaction between \% WCO and fire frequency (Table 2). Analyses of subsets of plots selected to isolate either fire frequency or \% WCO led to similar conclusions.

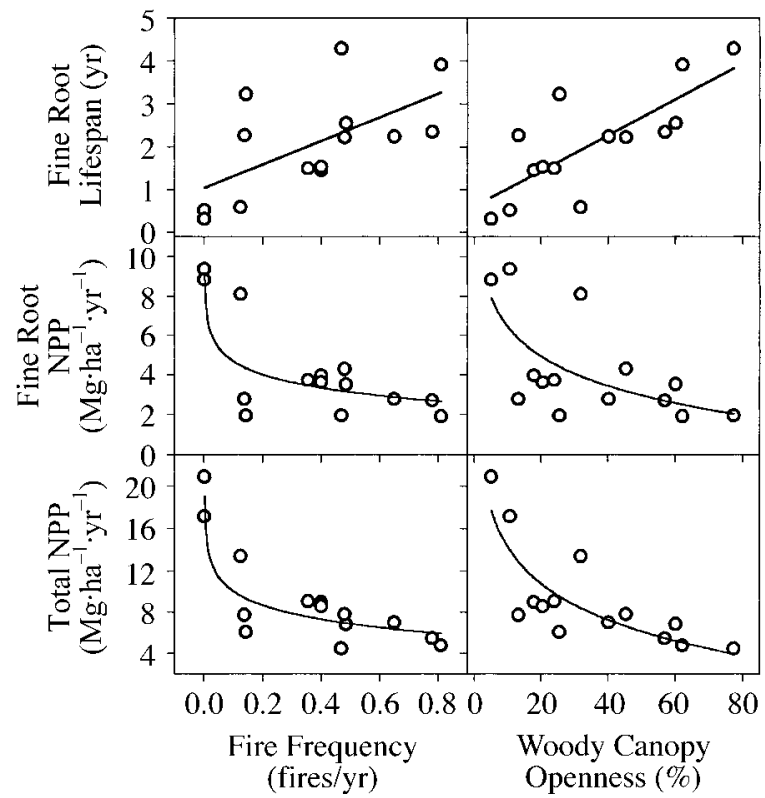

FIG. 8. Estimated fine root longevity, estimated fine root NPP, and estimated total NPP, in relation to fire frequency $\left(r^{2}\right.$ $=0.37,0.70$, and 0.83 , respectively) and percentage of woody canopy openness $\left(r^{2}=0.60,0.42\right.$, and 0.67 , respectively), for 20 woodland and savanna stands. All relationships are significant at $P<0.001$.
When we restricted our analysis to the seven plots with intermediate fire frequency (burned once every two to three years), there were still strong relations (Fig. 10) of most factors with \%WCO (which varied widely among the seven plots). ANPP, net $\mathrm{N}$ mineralization rates, root turnover rates, and canopy $\mathrm{N}$ were much greater in tree- than grass-dominated communities. When we examined only the 10 most woody-dominated

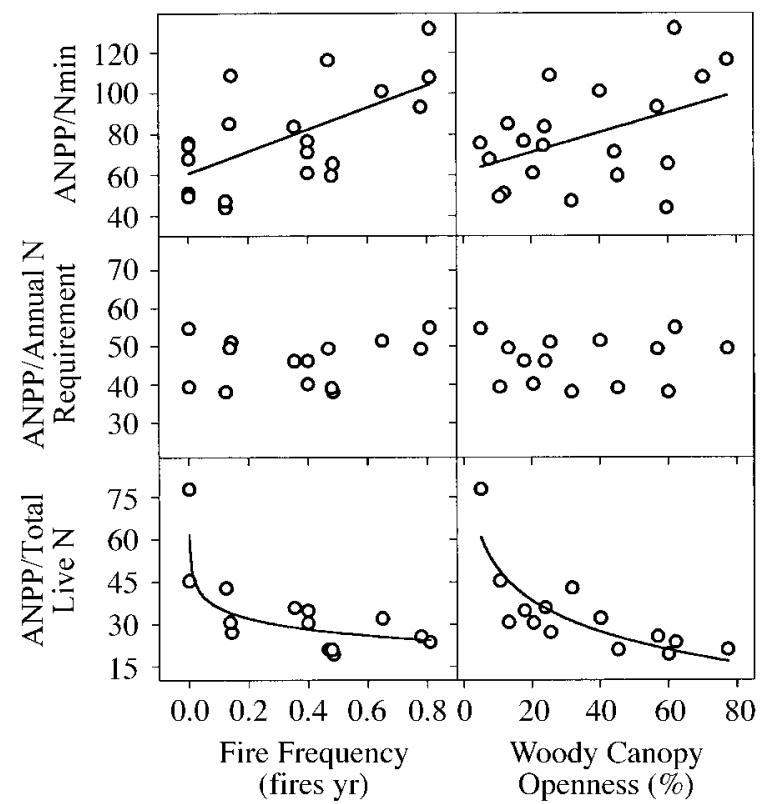

FIG. 9. Several measures of $\mathrm{N}$ use efficiency (NUE): ANPP per unit $\mathrm{N}$ mineralized (ANPP/Nmin); ANPP per annual $\mathrm{N}$ requirement, and ANPP per total live tissue $\mathrm{N}$ in relation to fire frequency $\left(r^{2}=0.38\right.$, NS, and 0.68 , respectively), and percent woody canopy openness $\left(r^{2}=0.20\right.$, NS, and 0.70 , respectively), for 20 woodland and savanna stands. Relationships are either significant at $P<0.05$ or labeled Ns. 
TABLE 2. Summary of multiple regression analyses for ecosystem traits in relation to fire frequency, percentage of woody canopy openness $(\% \mathrm{WCO})$, and their interaction.

\begin{tabular}{|c|c|c|c|c|c|c|c|c|}
\hline \multirow{2}{*}{$\begin{array}{l}\text { Dependent } \\
\text { variable }\end{array}$} & \multicolumn{2}{|c|}{ Whole model } & \multicolumn{2}{|c|}{ Fire frequency } & \multicolumn{2}{|c|}{$\% \mathrm{WCO}$} & \multicolumn{2}{|c|}{ Interaction } \\
\hline & $P$ & $r^{2}$ & $P$ & $F$ & $P$ & $F$ & $P$ & $F$ \\
\hline ANPP & $<0.0001$ & 0.74 & 0.18 & 2.0 & 0.003 & 11.8 & 0.05 & 4.5 \\
\hline $\begin{array}{l}\text { Aboveground } \\
\text { biomass }\end{array}$ & $<0.0001$ & 0.73 & 0.28 & 1.2 & 0.003 & 12.2 & 0.02 & 6.7 \\
\hline $\begin{array}{l}\text { Fine root } \\
\text { biomass }\end{array}$ & $<0.0001$ & 0.57 & 0.98 & 0.0 & 0.03 & 6.4 & NS & \\
\hline $\begin{array}{l}\text { Total leaf area } \\
\text { index }\end{array}$ & $<0.0001$ & 0.67 & 0.14 & 2.5 & 0.02 & 6.5 & 0.06 & 4.1 \\
\hline Tree ANPP & $<0.0001$ & 0.72 & 0.19 & 1.9 & 0.006 & 10.1 & 0.04 & 4.8 \\
\hline Herb ANPP & $<0.0001$ & 0.96 & 0.36 & 0.9 & $<0.0001$ & 162.4 & 0.04 & 4.9 \\
\hline $\begin{array}{l}\text { Soil N } \\
\text { mineralization }\end{array}$ & $<0.0001$ & 0.67 & 0.04 & 4.9 & 0.05 & 4.4 & NS & \\
\hline $\begin{array}{l}\text { Annual litterfall } \\
\mathrm{N}\end{array}$ & $<0.0001$ & 0.79 & 0.09 & 3.2 & 0.001 & 16.0 & NS & \\
\hline $\begin{array}{l}\text { Total canopy } \\
\% \mathrm{~N}\end{array}$ & $<0.0001$ & 0.81 & 0.20 & 1.8 & $<0.0001$ & 38.0 & 0.05 & 4.5 \\
\hline
\end{tabular}

Notes: Degrees of freedom for tests of fire frequency, \%WCO, and their interaction: $(1,17)$ when interaction term removed from the model; $(1,16)$ with interaction term in the model; except for fine root biomass $(1,11)$. If the interaction term was not significant $(P>0.10)$ it was dropped from the model, and the model was re-run without it. NS $=$ not significant at $P<$ 0.10 .
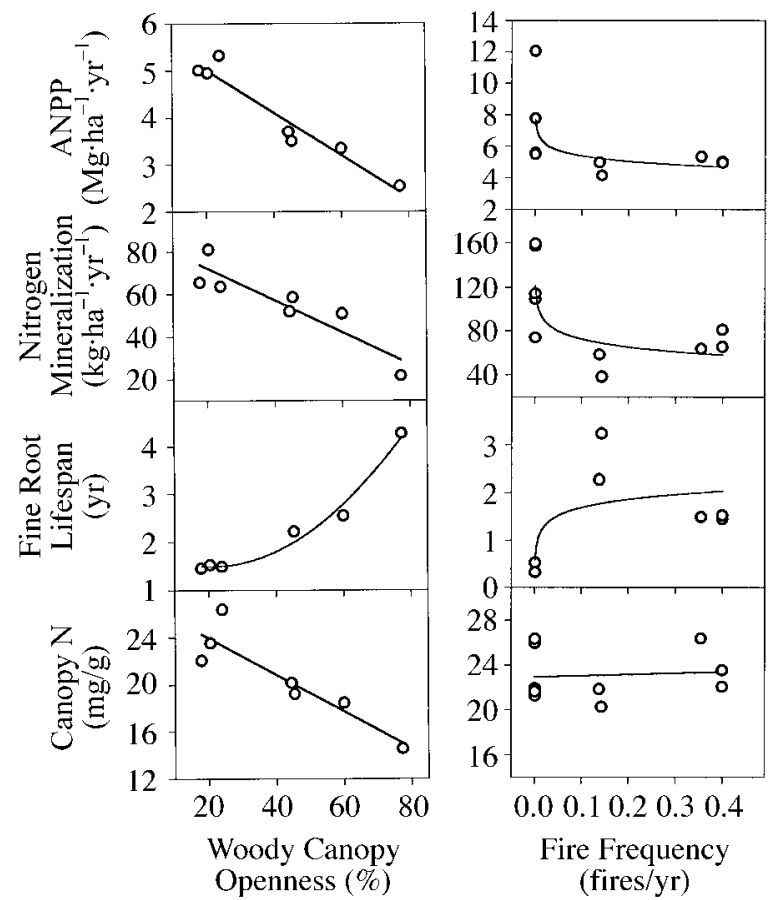

FIG. 10. Left column data are for seven stands of intermediate fire frequency (burned every two or three years): mean annual aboveground net primary production, annual net $\mathrm{N}$ mineralization rate, fine root longevity, and mean total canopy $\mathrm{N}$ concentration in relation to percentage woody canopy openness $\left(r^{2}=0.93,0.82,0.96\right.$, and 0.82 , respectively). All relationships are significant at $P<0.001$. Right column data are for 10 stands of $>75 \%$ woody canopy cover: mean ANPP, annual net $\mathrm{N}$ mineralization rate, fine root longevity, and mean total canopy $\mathrm{N}$ concentration in relation to fire frequency ( $r^{2}=0.39,0.56$, NS, and NS, respectively). Relationships are either significant at $P<0.05$ or labeled NS. plots (all with $>75 \%$ woody canopy cover), which vary from unburned to burned every other year, we still see a tendency for burned plots to have lower ANPP and $\mathrm{N}$ mineralization rates (Fig. 10), although these relationships were not as clear.

\section{DISCUSSION}

The results of this study indicate a close coupling between $\mathrm{C}$ (i.e., aboveground net primary production [ANPP]) and $\mathrm{N}$ cycling in temperate zone savannas and woodlands on infertile soils. This is similar to the relationship between productivity and $\mathrm{N}$ mineralization among forests in this region (Reich et al. 1997). The linear increase in productivity with $\mathrm{N}$ supply in these studies over the range of variation observed suggests that the possible uncoupling of $\mathrm{C}$ and $\mathrm{N}$ (Asner et al. 1997) hypothesized due to chronic $\mathrm{N}$ deposition is not yet occurring in this region.

Rates of ANPP and N mineralization measured for the forested plots in this study were roughly comparable to the average from other studies in this region (Reich et al. 1997). How can we reconcile that with studies (Tilman 1987, Wedin and Tilman 1990) showing that a variety of vegetation types on sandy soils at Cedar Creek are $\mathrm{N}$ limited and unproductive? Perhaps these soils are capable of sustaining high ANPP and high soil $\mathrm{N}$ cycling when the vegetation contributes to the development of an active and rapidly turning over pool of $\mathrm{N}$, but they may be sensitive to degeneration of the $\mathrm{N}$ cycle during and after agriculture or other severe disturbance.

Our findings were opposite of those of Mitchell et al. (1999a) who found a negative relationship between soil net $\mathrm{N}$ mineralization and ANPP in wire-grass/pine savannas in the southeastern USA. Although this appears contradictory, it may reflect differential drivers 
of ecosystem productivity and different sampling designs: Mitchell et al. (1999a) selected sites that vary extremely in water availability, and found strong relations between water supply and ANPP across this gradient. In contrast, our data indicate a positive coupling of N supply and ANPP, when comparing sites of similar soil water holding capacity.

Our results also differ from those of Wedin and Tilman (1990) for grass monocultures at Cedar Creek, and Turner et al. (1997) for grasslands in Kansas, USA. Wedin and Tilman (1990) found a negative relationship between productivity and $\mathrm{N}$ mineralization among species that resulted from strong differential species effects on N cycling. Similarly, although Turner et al. (1997) and Knapp et al. (1998) found that N fertilization increased productivity in Kansas grasslands, especially those that were frequently burned, there was not a close relationship between ANPP and N mineralization either within burned or unburned plots or across plots varying in fire frequency, and the relationship tended to be negative (Turner et al. 1997). Increasing fire frequency sometimes reduced soil net N mineralization rates (Blair 1997, Blair et al. 1998, Turner et al. 1997), and even when $\mathrm{N}$ mineralization rates were reduced, ANPP was not. Apparently the positive effects of fire on grassland ANPP, by elimination of detrital shading, can offset the negative effects due to reduced N supply (Blair et al. 1998, Knapp et al. 1998). Turner et al. (1997) concluded that controls of grassland soil $\mathrm{N}$ mineralization and productivity operate somewhat independently, providing an explanation for a more widespread lack of correlation between ANPP and $\mathrm{N}$ availability in tallgrass prairie (Knapp et al. 1998) than in forested ecosystems (Reich et al. 1997).

An important distinction between these grassland studies and our savanna study involves the role of the woody plants. In the present study, the large variation in intrinsic properties (e.g., LAI, percentage of N) of tree- vs. grass-dominated communities and their influence over time on ecosystem processes and properties may lead to marked divergence in both $\mathrm{C}$ and $\mathrm{N}$ cycling as communities becoming increasingly or decreasingly woody dominated. Detrital shading is not an important control on woody vegetation NPP and hence there is no compensating positive effect of frequent fire on ANPP that offsets the negative impact of reduced $\mathrm{N}$ availability. Even when fire might stimulate herbaceous productivity, this is likely to be of smaller magnitude than the loss of potential woody productivity due to the absence of trees. In the following section we consider our study results within the framework of the original hypotheses.

Hypotheses \#1 and \#2. Productivity and $N$ cycling rates will be negatively related to fire frequency and positively related to tree dominance.-The results support the idea that both direct and indirect effects of fire will shift $\mathrm{C}$ and $\mathrm{N}$ cycling in the same direction. Much of the rest of the discussion will address a variety of ways in which these processes appear to operate (see Synthesis and integration).

Hypothesis \#3. Grass-dominated stands will have a greater root biomass, root productivity and proportional distribution of both biomass and productivity belowground than tree-dominated stands.-As hypothesized, fine root biomass was greater in grass- than tree-dominated communities. This was apparently not due to greater belowground net primary production (BNPP) or greater proportional allocation to roots, but to lower root turnover rates. The patterns of BNPP were opposite to the hypothesis (being greater in woodlandthan grassland-dominated plots) and the relative proportion of NPP to roots vs. shoots did not differ between grass- and tree-dominated communities.

The size of the fine root system relative to that of the canopy may be an important functional characteristic. A dynamic functional balance model (extended from Shinozaki et al. $1964 a, b$ ) suggests that the ratio between foliage mass and fine root mass varies depending upon the relative supply of aboveground vs. belowground resources (as well as on species, stand age, and other factors). It is generally hypothesized that the ratio of fine roots to foliage will increase as nutrient supply decreases (Santantonio 1989, Cropper and Gholz 1994). Data from this study (Fig. 2) support that idea, since the grass-dominated ecosystems where $\mathrm{N}$ supply is low have greater fine root: foliage ratios than the woody-dominated systems where $\mathrm{N}$ supply is greater. However, it is impossible to separate out how much of this difference is due to shifts in root vs. foliage ratio within a vegetation type (trees or grasses) vs. differences in composition among those types.

The $\mathrm{N}$ budgeting approach to estimating mean residence time (MRT) of N, fine root longevity, and BNPP has a number of untested assumptions, and hence a degree of uncertainty associated with the estimates, as does every other available method (Vogt et al. 1998, Fahey et al. 1999). Thus it is likely that differences in fine root turnover and production between tree- and grass-dominated communities at Cedar Creek reflect general patterns, although the degree of uncertainty regarding the absolute values and differences is unknown. However, these data are consistent with differences in estimated root turnover rates of roughly one growing season or less in eastern N. American forests (Nadelhoffer et al. 1985, Hendrick and Pregitzer 1992, Eissenstat and Yanai 1997) vs. 2-3 yr or more in Great Plains grasses (Weaver and Zink 1946, Milchunas and Lauenroth 1992).

Hypothesis \#4. Differences in ANPP between woodyand grass-dominated communities result from differences in $N$ availability and $N$ use efficiency.-The treedominated plots had lower NUE by several measures (refuting hypotheses $4 \mathrm{a}$ and $4 \mathrm{~b}$ ), but a much greater annual $\mathrm{N}$ cycle (defined as either litterfall $\mathrm{N}$ or net soil $\mathrm{N}$ mineralization) which more than offset the lower 
NUE in terms of impacts on ANPP (supporting hypothesis 4c). Hypothesis 4d-that differences in ANPP result from proportional differences in distribution of (similar) NPP above vs. below ground-was also refuted, since these communities did not differ in the proportion of NPP allocated below vs. above ground.

Both low tissue turnover rates and enhanced $\mathrm{N}$ resorption have received much attention as possible adaptations of species common to infertile habitats, influencing individual plant nutrient budgets, and indirectly influencing biogeochemical cycles (e.g., May and Killingbeck 1992, Reich et al. 1992). At Cedar Creek, differences in belowground tissue turnover rates appear to be important vis-à-vis the $\mathrm{N}$ cycle of treevs. grass-dominated savanna communities, but leaves of all important species are shed annually, hence eliminating turnover rate as an important aboveground component of $\mathrm{N}$ cycling. In contrast, the tissue chemistry of the oak species at Cedar Creek varied in relation to available soil $\mathrm{N}$-leaves had greater $\mathrm{N}$ resorption and hence greater litterfall $\mathrm{C}: \mathrm{N}$ ratios in stands with low $\mathrm{N}$ mineralization rates. This suggests that the "slow down" of $\mathrm{N}$ cycling due to frequent fire and the feedbacks of the dominant grasses also influences the trees litter chemistry, further "pushing" the system in the same direction. Several studies in the past decade have demonstrated that there is no general tendency for species with low leaf turnover rates or low nutrient concentrations, or those common to low nutrient habitats, to resorb any greater fraction of their leaf $\mathrm{N}$ than those species with faster leaf turnover rates or greater leaf nutrient concentrations, or those common to more fertile habitats (e.g., Reich et al. 1992, 1995, Aerts 1996). In contrast, the evidence here for proportionally greater $\mathrm{N}$ resorption in oaks that grew under limited $\mathrm{N}$ supply suggests that acclimation in resorption efficiency may be important. This evidence is consistent with the small number of studies where resorption efficiency was assessed in response to manipulation of $\mathrm{N}$ supply (e.g., Shaver 1983). Variation in the composition of the herbaceous component of the community (Peterson 1998) which likely results from the combination of fire and shading, also contributes to the gradient in litter $\mathrm{N}$, since the shade-tolerant/fire-intolerant species in the woody-dominated end of the continuum have higher tissue percentage $\mathrm{N}$ than those dominant at the other end.

\section{Synthesis and integration}

Differences in $C$ and $N$ cycling rates among functional types.-Why are $\mathrm{C}$ and $\mathrm{N}$ cycling rates so much higher in tree- than grass-dominated communities and in unburned than frequently burned ones? Both fire and vegetation controls on ecosystem functioning are likely involved (Fig. 11). Our results are consistent with two basic and related ideas: first, that NPP is a function of the amount of radiation intercepted and the efficiency with which intercepted radiation is converted to bio- mass $(\mathrm{NPP}=$ light intercepted $\times$ light use efficiency, with the latter defined as productivity per unit light intercepted), and second, that NPP is related to the amount of $\mathrm{N}$ allocated to a canopy and the efficiency with which that $\mathrm{N}$ is utilized to capture carbon (NPP = canopy $\mathrm{N} \times$ canopy $\mathrm{N}$ productivity, with the latter defined as productivity per unit canopy N). Total ANPP was positively related to LAI (i.e., interception), annual $\mathrm{N}$ requirement, and canopy $\mathrm{N}$. Moreover, total light use efficiency was higher in tree-dominated communities that had higher $\mathrm{N}$ mineralization rates than the grassdominated plots (data not shown). Hence, at Cedar Creek, productivity is greater in tree- than grass-dominated systems largely because they have higher LAI and total canopy $\mathrm{N}$ (greater interception of radiation and total biochemical capacity to use the intercepted light) and greater annual $\mathrm{N}$ supply. In contrast, grassdominated communities have lower NPP because low turnover rates of root $\mathrm{N}$ lead to low amounts of litter $\mathrm{N}$, and hence to low soil $\mathrm{N}$ mineralization rates. This in turn leads to low available $\mathrm{N}$ to build the next canopy (Fig. 11) and a small canopy with low total $\mathrm{N}$ leads to low $\mathrm{C}$ gain (despite the greater photosynthetic $\mathrm{N}$ use efficiency).

What are the links between light use efficiency, and $\mathrm{C}$ and $\mathrm{N}$ cycling? Some minimum amount of $\mathrm{N}$ and other nutrients is needed to support a given biomass or LAI (Fig. 11). The greater LAI of the woody communities could occur with a lower mean canopy percentage $\mathrm{N}$ (i.e., deploying $\mathrm{N}$ efficiently over a larger canopy), or with a much greater annual $\mathrm{N}$ uptake, which appears to be the case. In order for tree-dominated communities to have high LAI and leaf percentage $\mathrm{N}$ they must also have higher annual $\mathrm{N}$ requirements. These higher $\mathrm{N}$ requirements are supported (Fig. 11) indirectly by a large annual litter $\mathrm{N}$ input (both above and below ground) of organic matter of higher tissue quality (lower C:N ratio) and more directly by the greater annual net $\mathrm{N}$ mineralization. Thus, higher NPP requires higher rates of $\mathrm{N}$ cycling, but higher rates of $\mathrm{N}$ cycling also require higher rates of NPP.

Relative roles of vegetation feedbacks and fire.-Fire reinforces and stabilizes the grass-dominated system. In any given year, fire increases the availability of light to grasses by consuming litter, and subsequently increases their productivity (Knapp et al. 1998). Across decades, frequent fire keeps the woody vegetation from successfully dominating the canopy by frequent stem killing (Peterson and Reich 2001). Volatilization of N occurs with fire and losses due to prescribed burning have been estimated as $10-40 \mathrm{~kg} \mathrm{~N} \cdot \mathrm{ha}^{-1} \cdot \mathrm{yr}^{-1}$ (Ojima et al. 1990, Blair et al. 1998). Given that $\mathrm{N}$ deposition inputs at Cedar Creek are $\sim 5-10 \mathrm{~kg} \mathrm{~N} \cdot \mathrm{ha}^{-1} \cdot \mathrm{yr}^{-1}$, frequent fires should lead to a net loss of $\mathrm{N}$ capital. In addition to the $\mathrm{N}$ losses from volatilization at Cedar Creek, the $\mathrm{N}$ cycle is further depressed in grass-dominated stands by the combination of slow root turnover, a slow total biomass cycle, and the adverse effects on 


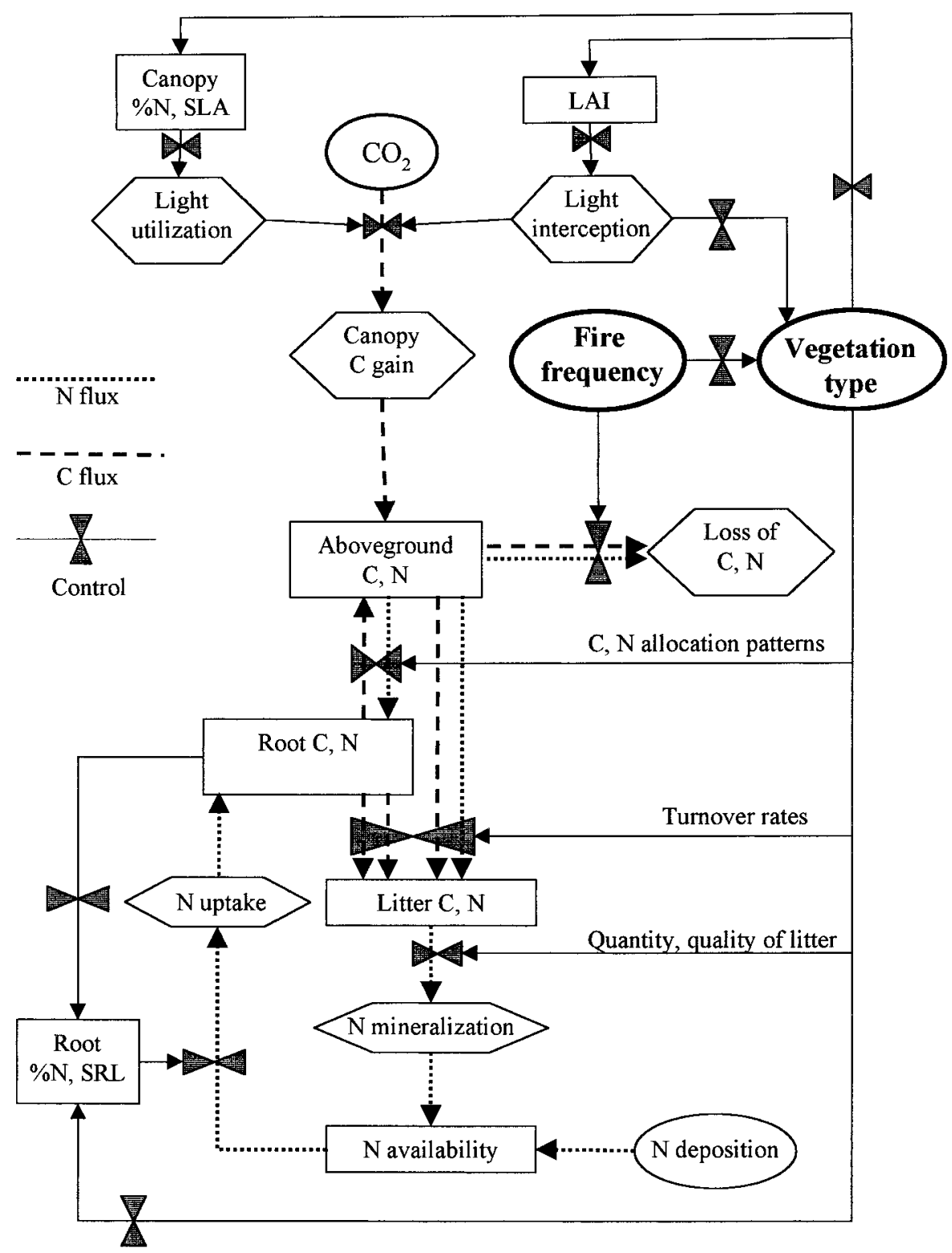

FIG. 11. Conceptual diagram of the influence of fire frequency and vegetation type (largely contrasting woody vs. grassdominated) on processes controlling fluxes and pools of carbon (C) and nitrogen (N) in savanna communities at Cedar Creek, Minnesota, USA. Pools are represented by boxes; fluxes by dark dotted ( $\mathrm{N}$ flux) and dashed (C flux) lines, respectively; controls by thin lines with valves; processes by hexagonal outlines; and external or state factors by oval outlines.

decomposition rates of poor tissue quality (Fig. 11; Wedin and Tilman 1990, Blair et al. 1998). These are likely the factors responsible for the rate of soil $\mathrm{N}$ mineralization being strongly related to vegetation type and fire frequency. If herbivore pressures were sufficiently low, $\mathrm{N}$-fixing legumes would be more abundant in frequently burned savanna at Cedar Creek and partially ameliorate the depression of $\mathrm{N}$ cycling, but deer densities are elevated above presettlement levels and suppress legumes in these communities (Ritchie et al. 1998).

Frequent fire limits tree dominance in temperate sa- vannas by limiting recruitment of new individuals to less than the rate of attrition of mature individuals (Peterson and Reich 2001) and thus promotes dominance by shade-intolerant grasses. However, without fire, substantial numbers of trees recruit over a matter of decades. Thus, in contrast to the impact of frequent fire, the absence of fire reinforces and stabilizes the treedominated system. Under natural fire regimes, forests reduce the probability of fire as a result of higher litter and surface soil moisture, lower temperatures, and higher humidity than grasslands. Without fire, the $\mathrm{C}$ and N cycles and NPP are stimulated for the reasons 
outlined above, and continued woody recruitment occurs, given the relatively high shade tolerance and low fire tolerance of woody regeneration. These fire-vegetation interactions collectively result in a two-way feedback switch (sensu Wilson and Agnew 1992). Even for plots with similar fire frequency, the rate of $\mathrm{N}$ mineralization tripled with increasing tree dominance (Fig. 10), and these wooded plots also had greater LAI, leaf percentage $\mathrm{N}$ and total canopy $\mathrm{N}$, and litter tissue percentage $\mathrm{N}$ than grass-dominated ones (see Fig. 10). These vegetation-related differences are likely responsible for a substantial part of the differences in soil net $\mathrm{N}$ mineralization rates between tree- and grass-dominated zones in this study.

The shade cast by trees and shrubs in these savannas and woodlands appears to be the main limit on herbaceous productivity and on the abundance and cover of grass species (Peterson 1998), despite much evidence that variation in $\mathrm{N}$ supply can influence grass productivity at Cedar Creek (Tilman 1987). It is possible that grasses are more sensitive to shade than to $\mathrm{N}$ supply, over the range of availabilities of the two key resources in the savanna gradient at Cedar Creek. In Kansas grasslands, shade is also an important regulator of grass ANPP (Knapp et al. 1998), although in that system shade is caused by litter accumulation when stands go unburned.

Collectively, these patterns lend support to the positive-feedback hypothesis (hypothesis 5). Although fire clearly can have a large influence, even in plots with similar fire frequency, tree- and grass-dominated stands appear to be divergent in productivity and $\mathrm{N}$ cycling. In summary, these results (Fig. 11) indicate that in comparing grass-dominated to tree-dominated assemblages (1) intrinsic differences in the size and chemistry of the green canopy lead to differences in NPP, (2) intrinsic differences in the allocational priorities or turnover rates of grasses and trees lead to different fine root: foliage ratios, (3) intrinsic differences in the fine root $\mathrm{N}$ residence times and litter chemistry (both foliage and fine roots) lead to differences in the rates of soil $\mathrm{N}$ mineralization, and (4) rates of soil $\mathrm{N}$ mineralization promote further differentiation in canopy size and $\mathrm{N}$ and in rates of carbon capture, bringing the feedback loop back in upon itself in a repeating cycle.

\section{ACKNOWLEDGMENTS}

We thank Dan Bahauddin, Laura Prugh, Shibu Jose, and Cindy Buschena for assisting with the field work, with laboratory processing of samples, and with data management; and John Blair and two anonymous reviewers for helpful criticism. This research was supported by the National Science Foundation Long-Term Ecological Research Program (DEB-9411972).

\section{Literature Cited}

Aber, J. D., J. M. Melillo, K. J. Nadelhoffer, and P. J. McClaugherty. 1985. Fine root turnover in forest ecosystems in relation to quantity and form of nitrogen availability: a comparison of two methods. Oecologia 66:317321.
Aerts, R. 1990. Nutrient use efficiency in evergreen and deciduous species from heathlands. Oecologia 84:391-397.

Aerts, R. 1992. Root turnover as determinant of the cycling of $\mathrm{C}, \mathrm{N}$ and $\mathrm{P}$ in a dry heathland ecosystem. Biogeochemistry 15:175-190.

Aerts, R. 1996. Nutrient resorption from senescing leaves of perennials: are there general patterns? Journal of Ecology 84:597-608.

Alemdag, I. S. 1983. Total tree and merchantable stem biomass equations for Ontario hardwoods. Canadian Forestry Service, Petawawa National Forestry Institute, Chalk River, Ontario, Canada. Information report PI-X-46.

Asner, G. P., T. R. Seastedt, and A. Townsend. 1997. The decoupling of terrestrial carbon and nitrogen cycles. BioScience 47:226-234.

Belsky, A. J. 1994. Influences of trees on savanna productivity: tests of shade, nutrients, and tree-grass competition. Ecology 75:922-932.

Berendse, F., and R. Aerts. 1987. Nitrogen-use-efficiency: a biologically meaningful definition? Functional Ecology 1: 293-296.

Binkley, D. 1995. The influence of tree species on forest soils: processes and patterns. Pages 1-32 in J. D. Mead and I. S. Cornforth, editors. Proceedings of the trees and soil workshop. Lincoln University, 28 February-2 March 1994. Agronomy Society of New Zealand Special Publication number 10. Lincoln University Press, Canterbury, New Zealand.

Blair, J. M. 1997. Fire, N availability, and plant response in grasslands: a test of the transient maxima hypothesis. Ecology 78:2359-2368.

Blair, J. M., T. R. Seastedt, C. W. Rice, and R. A. Ramundo. 1998. Terrestrial nutrient cycling in tallgrass prairie. Pages 222-243 in A. K. Knapp, J. M. Briggs, D. C. Hartnett, and S. C. Collins, editors. Grassland dynamics: long-term ecological research in tallgrass prairie. Oxford University Press, New York, New York, USA.

Cropper, W. P. J., and H. L. Gholz. 1994. Evaluating potential response mechanisms of a forest stand to fertilization and night temperature: a case study using Pinus elliottii. Ecological Bulletins 43:154-160.

Davis, M. A., K. J. Wrage, and P. B. Reich. 1998. Competition between tree seedlings and herbaceous vegetation: support for a theory of resource supply and demand. Journal of Ecology 86:652-661

Eissenstat, D. M., and R. D. Yanai. 1997. The ecology of root lifespan. Advances in Ecological Research 27:2-60.

Fahey, T. J., C. S. Bledsoe, F. P. Day, R. W. Reuss, and A. J. M. Smucker. 1999. Fine root production and demography. Pages 437-455 in G. P. Robertson, D. C. Coleman, and C. S. Bledsoe, editors. Standard soil methods for longterm ecological research. Oxford University Press, New York, New York, USA.

Gholz, H. L., S. Linder, and R. E. McMurtrie, editors. 1994. Environmental constraints on the structure and productivity of pine forest ecosystems: a comparative analysis. Ecological Bulletins number 43. Munksgaard International Publishers, Copenhagen, Denmark.

Gordon, D. R., J. M. Welker, J. W. Menke, and K. J. Rice. 1989. Competition for soil water between annual plants and blue oak (Quercus douglasii) seedlings. Oecologia 79: 533-541.

Gower, S. T., P. B. Reich, and Y. Son. 1993. Canopy dynamics and aboveground production of five tree species with different leaf longevities. Tree Physiology 12:327-345.

Gower, S. T., and Y. Son. 1992. Differences in soil and leaf litterfall nitrogen dynamics for five forest plantations. Soil Science Society of America Journal 56:1959-1966.

Gower, S. T., K. A. Vogt, and C. C. Grier. 1992. Carbon dynamics of Rocky Mountain Douglas-fir: influence of wa- 
ter and nutrient availability. Ecological Monographs 63: 43-65.

Grigal, D. F., L. M. Chamberlain, H. R. Finney, V. Wroblewski, and E. R. Gross. 1974. Soils of the Cedar Creek Natural History Area. Miscellaneous Report 123, University of Minnesota Agricultural Experimental Station, St. Paul, Minnesota, USA.

Haworth, K., and G. R. McPherson. 1994. Effects of Quercus emoryi trees on herbaceous vegetation in a semi-arid savanna. Vegetatio 112:153-159.

Hendrick, R. L., and K. S. Pregitzer. 1992. The demography of fine roots in a northern hardwood forest. Ecology 73: 1094-1104.

Jackson, L. E., R. B. Strauss, M. K. Firestone, and J. W. Bartolome. 1990. Influence of tree canopies on grassland productivity and nitrogen dynamics in deciduous oak savanna. Agriculture, Ecosystems and Environment 32:89105.

Jackson, R. B., J. Canadell, J. R. Ehleringer, H. A. Mooney, O. E. Sala, and E. D. Schulze. 1996. A global analysis of root distributions for terrestrial biomes. Oecologia 108: 389-411.

Knapp, A. K., J. M. Briggs, J. M. Blair, and C. L. Turner. 1998. Patterns and controls of aboveground net primary production in tallgrass prairie. Pages 193-221 in A. K. Knapp, J. M. Briggs, D. C. Hartnett, and S. C. Collins, editors. Grassland dynamics: long-term ecological research in tallgrass prairie. Oxford University Press, New York, New York, USA.

Knapp, A. K., J. T. Fahnestock, S. P. Hamburg, L. B. Statland, T. R. Seastedt, and D. S. Schimel. 1993. Landscape patterns in soil-plant water relations and primary production in tallgrass prairie. Ecology 74:549-560.

Kramer, P. J., and T. T. Kozlowski. 1979. Physiology of woody plants. Academic Press, Orlando, Florida, USA.

Kucera, C. L., and M. Koelling. 1964. The influence of fire on composition of central Missouri prairie. American Midland Naturalist 72:142-147.

Long, S. P. 1999. Environmental responses. Pages 215-249 in R. F. Sage and R. K. Monson, editors. $\mathrm{C}_{4}$ plant biology. Academic Press, Orlando, Florida, USA.

May, J. D., and K. T. Killingbeck. 1992. Effects of preventing nutrient resorption on plant fitness and foliar nutrient dynamics. Ecology 73:1868-1878.

Milchunas, D. G., and W. K. Lauenroth. 1992. Carbon dynamics and estimates of primary production by harvest, 14C dilution, and 14C turnover. Ecology 73:593-607.

Mitchell, R. J., L. K. Kirkman, S. D. Pecot, C. A. Wilson, B. J. Palik, and L. R. Boring. 1999a. Patterns and controls of ecosystem function in longleaf pine and wiregrass savannas. I. Aboveground net primary productivity. Canadian Journal of Forest Research 29:743-751.

Mitchell, R. J., B. R. Zutter, D. H. Gjerstad, G. R. Glover, and C. W. Wood. 1999b. Competition among secondarysuccessional pine communities: a field study of effects and responses. Ecology 80:857-872.

Mooney, H., J. Roy, and B. Saugier, editors. 2000. Global terrestrial productivity. Academic Press, Orlando, Florida, USA.

Nadelhoffer, K. J., J. D. Aber, and J. M. Melillo. 1985. Fine roots, net primary production, and soil nitrogen availability: a new hypothesis. Ecology 66:1377-1390.

Nambiar, E. K. S. 1987. Do nutrients retranslocate from fine roots? Canadian Journal of Forest Research 17:913-918.

Nuzzo, V. A. 1986. Extent and status of Midwest oak savanna: presettlement and 1985. Natural Areas Journal 6: 6-36.

Ojima, D. S., D. S. Schimel, W. J. Parton, and C. E. Owensby. 1994. Long- and short-term effects of fire on nutrient cycling in tallgrass prairie. Biogeochemistry $\mathbf{2 4}$ : 67-84.

Pastor, J., J. D. Aber, C. A. McClaugherty, and J. M. Melillo. 1984. Aboveground production and $\mathrm{N}$ and $\mathrm{P}$ cycling along a nitrogen mineralization gradient on Blackhawk Island, Wisconsin. Ecology 65:256-268.

Peterson, D. W. 1998. Fire effects on oak savanna and woodland vegetation in Minnesota. Dissertation. University of Minnesota, St. Paul, Minnesota, USA.

Peterson, D. W., and P. B. Reich. 2001. Fire frequency and stand dynamics in an oak savanna-woodland ecosystem. Ecological Applications 11:914-927.

Raison, R. J. 1979. Modifications of the soil environment by vegetation fires, with particular reference to nitrogen transformations: a review. Plant and Soil 51:73-108.

Reich, P. B., M. D. Abrams, D. S. Ellsworth, E. L. Kruger, and T. J. Tabone. 1990. Fire affects ecophysiology and community dynamics of central Wisconsin oak forest regeneration. Ecology 71:2179-2190.

Reich, P. B., D. S. Ellsworth, and C. Uhl. 1995. Leaf carbon and nutrient assimilation and conservation in species of differing successional status in an oligotrophic Amazonian forest. Functional Ecology 9:65-76.

Reich, P. B., D. F. Grigal, J. D. Aber, and S. T. Gower. 1997. Nitrogen mineralization and productivity in 50 hardwood and conifer stands on diverse soils. Ecology 78:335-347.

Reich, P. B., M. B. Walters, and D. S. Ellsworth. 1992. Leaf lifespan in relation to leaf, plant, and stand characteristics among diverse ecosystems. Ecological Monographs 62: 365-392.

Risser, P. G., C. E. Birney, H. D. Blocker, S. W. May, W. J. Parton, and J. A. Weins. 1981. The true prairie ecosystem. US/IBP synthesis series 16. Hutchinson Ross, Stroudsburg, Pennsylvania, USA.

Ritchie, M. E., D. Tilman, and J. M. H. Knops. 1998. Herbivore effects on plant and nitrogen dynamics in oak savanna. Ecology 79:165-177.

Santantonio, D. 1989. Dry-matter partitioning and fine-root production in forests-new approaches to difficult problems. Pages 57-72 in J. S. Periera and J. J. Landsberg, editors. Biomass production by fast-growing trees. Kluwer Academic Publishers, Dordrecht, The Netherlands.

Scholes, R. J., and S. R. Archer. 1997. Tree-grass interactions in savannas. Annual Review of Ecology and Systematics 28:517-544.

Shaver, G. R. 1983. Mineral nutrition and leaf longevity in an evergreen shrub, Ledum palustre: the role of individual nutrients and the timing of leaf mortality. Oecologia 56: $160-165$.

Shinozaki, K., K. Yoda, K. Hozumi, and T. Kira. 1964a. A quantitative analysis of plant form-the pipe model theory. I. Basic analyses. Japanese Journal of Ecology 14:7-105.

Shinozaki, K., K. Yoda, K. Hozumi, and T. Kira. 1964b. A quantitative analysis of plant form-the pipe model theory. II. Further evidence of the theory and its application in forest ecology. Japanese Journal of Ecology 14:133-139.

Tateno, M., and F. S. Chapin III. 1997. The logic of carbon and nitrogen interactions in terrestrial ecosystems. American Naturalist 149:723-744.

Tilman, D. 1987. Secondary succession and the pattern of plant dominance along experimental nitrogen gradients. Ecological Monographs 57:189-214.

Turner, C. L., J. M. Blair, R. J. Shartz, and J. C. Neel. 1997. Soil N and plant responses to fire, topography, and supplemental $\mathrm{N}$ in tallgrass prairie. Ecology $\mathbf{7 8}$ : 1832-1843.

Turner, C. L., and A. K. Knapp. 1996. Responses of a $\mathrm{C}_{4}$ grass and three $\mathrm{C}_{3}$ forbs to variation in nitrogen and light in a tallgrass prairie. Ecology 77:1738-1749. 
Vitousek, P. M. 1982. Nutrient cycling and nutrient use efficiency. American Naturalist 119:553-572.

Vogt, K. A., D. J. Vogt, and J. Bloomfield. 1998. Analysis of some direct and indirect methods for estimating root biomass and production of forests at an ecosystem level. Plant and Soil 200:71-892.

Weaver, J. E., and E. Zink. 1946. Length of life of roots of ten species of perennial range and pasture grasses. Plant Physiology 24:201-217.
Wedin, D. A., and D. Tilman. 1990. Species effects on nitrogen cycling: a test with perennial grasses. Oecologia 84: 433-441.

Wedin, D. A., and D. Tilman. 1995. Influence of nitrogen loading and species composition on the carbon balance of grasslands. Science 274:1720-1723.

Wilson, J. B., and A. D. Q. Agnew. 1992. Positive feedback switches in plant communities. Advances in Ecological Research 23:263-336. 